\title{
Do Borrower Rights Improve Borrower Outcomes? Evidence from the Foreclosure Process
}

\section{Kristopher Gerardi, Lauren Lambie-Hanson, and Paul S. Willen}

\begin{abstract}
:
The authors evaluate laws designed to protect borrowers from foreclosure. They find that these laws delay but do not prevent foreclosures. They first compare states that require lenders to seek judicial permission to foreclose with states that do not. Borrowers in judicial states are no more likely to cure and no more likely to renegotiate their loans, but the delays lead to a buildup in these states of persistently delinquent borrowers, the vast majority of whom eventually lose their homes. They next analyze a "right-to-cure" law instituted in Massachusetts on May 1, 2008. Using a difference-in-differences approach to evaluate the effect of the policy, they compare Massachusetts with neighboring states that did not adopt similar laws. They find that the right-to-cure law lengthens the foreclosure timeline but does not lead to better outcomes for borrowers.
\end{abstract}

\section{JEL Classifications: G21, K11, R31}

Keywords: foreclosure, mortgage, judicial, power of sale, right to cure

Kristopher Gerardi is an economist and an assistant policy advisor at the Federal Reserve Bank of Atlanta. His email address is kristopher.gerardi@atl.frb.org. Lauren Lambie-Hanson is a graduate student in the department of urban studies and planning at the Massachusetts Institute of Technology and a graduate fellow in the research department at the Federal Reserve Bank of Boston. Her e-mail address is 1 slh@mit.edu. Paul S. Willen is a senior economist and policy advisor at the Federal Reserve Bank of Boston. His e-mail address is paul.willen@bos.frb.org.

The authors thank Jane Dokko, Bob Triest, and audiences at the Federal Reserve Bank of New York, the Massachusetts Institute of Technology, the Association of Collegiate Schools of Planning, and the Association for Public Policy Analysis and Management for helpful comments and suggestions and Elizabeth Murry for inspired editorial assistance. The discussion of foreclosure law in Section 3 benefited from many long conversations with Zachary Kimball and Richard Howe, Jr.

This paper, which may be revised, is available on the web site of the Federal Reserve Bank of Boston at http://www.bostonfed.org/economic/ppdp/index.htm.

This paper presents preliminary analysis and results intended to stimulate discussion and critical comment. The views expressed herein are those of the authors and do not indicate concurrence by other members of the research staff or the principals of the Federal Reserve Bank of Boston, the Federal Reserve Bank of Atlanta, or the Board of Governors of the Federal Reserve System.

This version: December 7, 2011 


\section{Introduction}

The progenitor of the U.S. residential mortgage first emerged in medieval England, and in the intervening 700 years, courts and legislators have established more and more protections for borrowers who default on their loans. Even today, many want to strengthen the laws even further. Researchers at the National Consumer Law Center argued in a recent policy paper that "antiquated state laws ... in some ways afford fewer protections to homeowners than to renters" and thus "[s]tates can and must do more to allow families to avoid foreclosure and preserve their homes and the wealth and savings embodied in them" (Rao and Walsh 2009, 3, 4).

In this paper, we measure the effectiveness of borrower protections by evaluating two policy interventions. The first is the right of a borrower to a judicial review of a foreclosure. Only 20 states, known as judicial states, provide for automatic judicial review, while the remaining 30 states, so-called power-of-sale states, allow the lender to foreclose without any judicial supervision. Thus it is possible to exploit variation across states to estimate the effectiveness of judicial review at preventing unnecessary foreclosures. But a problem with using state-level variation is that there is a strong regional pattern to judicial review; most judicial states are located in the Northeast, while power of sale predominates in the fastgrowing southern and western states. To address the potential omitted-variables problem generated by these regional patterns, we turn to a different intervention - a "right-to-cure" law that blocks lenders from starting foreclosure proceedings for a set period of time after a borrower defaults on his or her loan. We focus on the Massachusetts statute that took effect on May 1, 2008, in the midst of the worst foreclosure crisis in the state's history. We employ a difference-in-differences identification strategy that compares mortgage outcomes in Massachusetts before and after the law's implementation with outcomes in neighboring states that did not adopt such a law. By looking at the same state before and after the imposition of the law, we control for state effects, and by comparing changes in Massachusetts with changes in neighboring states, we control for time trends in borrower outcomes.

We measure the effects of the two policies using three metrics. First we look at foreclosures and find that both judicial foreclosure and the right-to-cure law have a dramatic effect on extending the foreclosure timeline. A year after a borrower enters serious default, which we define as becoming 90-days delinquent, lenders had auctioned off only 14 percent of properties in judicial states compared to 35 percent in power-of-sale states. The imposition of the right-to-cure law essentially brought foreclosure filings to a halt and led to a consistent 90-day delay in filings for all subsequent foreclosures. The effect of the right-to-cure statute on completed foreclosure auctions was much less pronounced, a point to which we return 
later.

The second metric involves looking at the likelihood of good outcomes, namely that a borrower in default subsequently "cures" the default by becoming current on the loan or by paying it off. We find that judicial intervention has no effect on cure rates. A year after default, 26.0 percent of borrowers in judicial states cure their default compared to 25.6 percent in power-of-sale states. When we focus on the imposition of the right-to-cure law in Massachusetts, we find similar effects. Over the same period, the difference in cure rates between borrowers who were subject to the protections of the right-to-cure law in Massachusetts mirror those of borrowers in neighboring states who did not have the same protections.

Some may see the large reduction in bad outcomes and no difference in good outcomes as contradictory. But there is no contradiction because of a third outcome: many borrowers languish in persistent delinquency, in which they neither cure their defaults nor lose their homes to foreclosure. In short, judicial intervention succeeds in temporarily reducing foreclosure by increasing the incidence of persistent delinquency. We show that persistently delinquent borrowers are unlikely to cure and that most eventually experience foreclosure. Over time, the foreclosure gap between judicial and power-of-sale states shrinks whereas the cure gap, or lack thereof, stays exactly the same. In other words, in the long run, a given number of defaults is expected to yield the same number of foreclosures regardless of the laws. These borrower-protection laws do not prevent foreclosure, they merely delay it.

The third metric for measuring the effect of lengthening the foreclosure timeline involves the likelihood of renegotiation between borrowers and lenders. One argument for increased borrower protection is that it may facilitate renegotiation-both directly, by allowing borrowers more time to make the case to their lender, and indirectly, by increasing borrowers' bargaining power. We find that prolonging the foreclosure process has no effect on the likelihood that a borrower receives a mortgage modification or, in the case of the right-to-cure law, on the difference in modification rates across states.

To better understand the dynamics of foreclosures and cures, we use a competing-risks hazard framework. Overall, both the instantaneous foreclosure hazard and cure hazard are significantly higher in power-of-sale states. To be clear, this fact means that delinquent borrowers in power-of-sale states are simultaneously more likely to be foreclosed on and more likely to become current or pay off their loans in any given month than are borrowers in judicial states.

While the institutional evidence provides a logical explanation for the higher foreclosure hazard in power-of-sale states, it is less obvious why the cure rate should also be higher. One possible explanation is that the longer period of living in the house without paying 
rent leads to more "strategic defaults" in judicial states. This in turn could negatively affect the mix of borrowers in the pool of defaulters, which could lead to a lower incidence of cure in judicial states. However, we show that the cure-rate gap only emerges three to five months after 90-day delinquency, which is inconsistent with the strategic-default explanation. Instead we argue, using a simple model, that unobserved heterogeneity across borrowers in both the cure hazard and foreclosure hazard can explain the precise patterns we observe. Specifically, we propose that lenders are less likely to foreclose on borrowers who are more likely to cure, either because those borrowers are more likely to contest the foreclosure or because lenders rationally provide more assistance to them. We show that an increased state-wide foreclosure rate leads to more foreclosures of those borrowers least likely to cure and improves the quality of the remaining pool of defaulters which, in turn, raises the cure hazard. We show that the precise patterns of the foreclosure and cure hazards fit this story well.

Based on this empirical evidence, we argue that judicial intervention indiscriminately slows down the foreclosure process. Essentially, the data suggest that in the first six months after becoming 90-days delinquent, foreclosures in power-of-sale states cull the borrowers least likely to cure, whereas extremely low foreclosure rates in judicial states allow such borrowers to continue to persist in delinquency. One logical explanation is that profitmaximizing lenders rationally provide a right-to-cure period by focusing their initial efforts on borrowers with little hope of curing. Another observationally equivalent possibility is that borrowers with little hope of curing are less likely to fight foreclosure. Either way, judicial intervention appears to block efficient foreclosure without promoting efficient resolutions.

We use two different data sets and a wide variety of specifications to check our results. In the main regressions, we use data provided by Lender Processing Services (LPS), which has the virtue of covering the entire U.S. mortgage market, including mortgages owned by investors in private-label mortgage-backed securities (MBS), loans in bank portfolios, and mortgages in pools insured by Fannie Mae and Freddie Mac. The LPS data, however, are only reliable for loans originated after 2004 and do not include information about second liens or any direct information about modifications or short sales. Because of these drawbacks, we also use data provided by CoreLogic; its data are reliable before 2004, include information about second liens, and have direct information about modifications and short sales. However, the CoreLogic data cover only loans that were held in private-label MBS deals.

The paper proceeds as follows. In the remainder of this section, we conduct a brief review of the existing literature on the effect of state laws on foreclosure patterns. In Section 2, we describe the data. In Section 3, we first discuss the nature and evolution of foreclosure 
law and the resulting differences in foreclosure laws across states. We then turn to the data and measure different outcomes in judicial and power-of-sale foreclosure states. Section 4 follows with a detailed discussion and analysis of the Massachusetts right-to-cure law.

Finally, in Section 5, we address the policy implications of our findings. We argue that both judicial intervention and the right-to-cure law fail at their stated goal of preventing unnecessary foreclosures. We then discuss other potential costs and benefits of the laws, including reducing the flow of bank-owned properties onto the market and increasing the number of persistently delinquent properties.

\subsection{Previous Literature}

A number of studies have examined the factors that lead borrowers to cure mortgage defaults rather than lose their properties to foreclosure. This literature generally agrees that borrowers are more likely to lose their properties to foreclosure (rather than cure or prepay) if they have spent more time in delinquency, have higher mortgage balances or lower levels of equity, or if their loans are less seasoned. However, the evidence is mixed on whether and how mortgage outcomes differ in judicial states compared to power-of-sale states.

In a study of 2,612 residential mortgages across the United States that were in default between 1987 and 1991, Phillips and Rosenblatt (1997) find that mortgages in judicial states were more likely to be resolved through foreclosure than those in power-of-sale states, whereas mortgages in power-of-sale states were more likely to be resolved through bankruptcy or a pre-foreclosure, lender-borrower negotiated sale than those in judicial states. ${ }^{1}$ Unfortunately, the authors offer no explicit information on the rate at which borrowers cure their mortgage defaults. Phillips and VanderHoff (2004) offer some evidence on the relationship between cure rates and state-level foreclosure laws, examining 1,907 fixedrate mortgages in default between 1988 and 1994. They find that cure and prepayment rates are higher in judicial as compared to power-of-sale states, though their results lack statistical significance.

In contrast to Phillips and Rosenblatt, Phillips and VanderHoff find evidence that the incidence of foreclosure is lower in judicial compared to power-of-sale states, though their results also lack statistical significance. Phillips and VanderHoff $(2004,586)$ argue that judicial foreclosure slows the foreclosure timeline and raises the costs faced by lenders, which amounts to a wealth transfer from lenders to borrowers and imposes dead-weight loss on society. On the other hand, Phillips and Rosenblatt, who find that loans in judicial states

\footnotetext{
${ }^{1}$ Because all of the borrowers in the sample had zero or negative equity, the authors assume that the pre-foreclosure sales must have required lender approval. Today we would call such transactions "short sales."
} 
are more likely to be terminated through foreclosure, point out that delinquent borrowers in power-of-sale states face more imminent threats of foreclosure and these borrowers demonstrate higher propensities to file for bankruptcy. They argue that bankruptcy, an outcome not examined by Phillips and VanderHoff (2004), should not be considered an efficient form of delinquency resolution.

More recent studies have focused on the current mortgage crisis. Pennington-Cross (2010) finds that among 5,000 non-prime mortgages in default, judicial foreclosure proceedings are associated with both lower cure and foreclosure rates; his results are highly significant and seem to suggest that the slower foreclosure proceedings in judicial states work to discourage borrowers from exiting default, either through good outcomes (paying off or becoming current on the mortgage) or bad outcomes (losing the property through foreclosure). Collins, Lam, and Herbert (2011) also study a sample of delinquent mortgages in the current crisis. In their sample of 8,000 mortgages held by a large national lender, they find no clear relationship between judicial foreclosure requirements and cure or foreclosure rates. However, they do find marginally significant evidence that loans in judicial foreclosure states have a higher probability of being modified when compared to similar loans that are in the same metropolitan statistical area but are located across the border in a power-of-sale state. The authors explain that modifications may be more common in judicial states, perhaps because the longer timeline allows borrowers greater opportunities to work with lenders or perhaps because it provides lenders with more incentive to modify loans, since the longer foreclosure process is more costly. However, the true mechanism underlying their results is unclear.

At first glance, it may seem that lenders should be eager to modify loans. ${ }^{2}$ Due to high foreclosure transaction costs and falling house prices, a lender repossessing a property through foreclosure typically loses half the value of a loan (Cordell and Shenoy 2011). Some estimates indicate that by modifying rather than foreclosing on loans, investors could save $\$ 180$ billion, which accounts to more than 1 percent of U.S. gross domestic product (Foote et al. 2010). Yet mortgage modifications are rare; Adelino, Gerardi, and Willen (2009) find that in a sample of seriously delinquent loans, fewer than 3 percent of borrowers

\footnotetext{
${ }^{2}$ In general, modifications fit into two categories: concessionary and non-concessionary agreements by lenders. When a lender grants a concessionary modification, it agrees to lower monthly payments, either by reducing interest rates, extending the term (time to maturation) of the mortgage, writing down some of the remaining principal balance of a mortgage, or some combination of these changes. These agreements can impose significant costs on lenders, both in the form of high monitoring costs as well as losses due to the decreased interest payments resulting from the modified contract terms. In contrast, non-concessionary modifications typically involve increasing the principal balance and result in higher payments from the capitalization of arrears into the mortgage balance. Non-concessionary modifications, which were used extensively before the foreclosure crisis, are traditionally more popular with lenders because they are cheaper than concessionary modifications (Adelino, Gerardi, and Willen 2009).
} 
received concessionary modifications in the first 12 months following their delinquency. Even a successful modification involves a long negotiation process between borrowers and lenders; lenders and servicers require extensive documentation from borrowers, which can take months to collect.

Finally, Mian, Sufi, and Trebbi (2011) argue that the differences in foreclosure laws studied in this paper provide an instrument for the number of foreclosures in a state. They use this instrument to suggest that increased numbers of foreclosures reduce house prices and economic activity. Our results show that their findings should be interpreted with great caution because the effect of the law is to delay, but not prevent, foreclosure. Without profound myopia on the part of home buyers, it is not obvious why spreading foreclosures over three years would lead to substantially less downward pressure on house prices than spreading foreclosures over two years.

Overall, most of the previous literature that has studied the effect of judicial laws on borrower outcomes has used very small samples that are not especially representative. ${ }^{3}$ As a result, it is difficult to determine whether the results of those studies can be extrapolated to the entire mortgage market. Additionally, those studies all utilize cross-sectional variation in judicial laws. In contrast, our present analysis uses nationally representative data from both the recent crisis period as well as the pre-crisis period; it also makes use of both cross-sectional and time-series variation to estimate the impact of judicial laws on borrower outcomes. Finally, our analysis of the right-to-cure law in Massachusetts allows us to make causal inferences about the impact of longer foreclosure timelines on borrower outcomes.

\section{Data}

Two main sources of data are used in our analysis. The primary data set comes from LPS and contains loan-level data that cover approximately 60 percent of residential mortgages nationwide, including those serviced by nine of the top ten mortgage servicers. ${ }^{4}$ The LPS data include detailed information on the characteristics and performance of both purchasemoney mortgages and mortgages used to refinance existing debt. ${ }^{5}$ The LPS data set is representative of the entire U.S. mortgage market because it contains loans that are held on the balance sheets of banks, loans securitized by the government-sponsored enterprises

\footnotetext{
${ }^{3}$ For example, Pennington-Cross (2010) only uses data for a single segment of the mortgage market and Collins, Lam, and Herbert (2011) only use data from a single mortgage lender.

${ }^{4}$ LPS is a servicer-based data set. Servicers that contribute to the data report the attributes and performance history of the mortgages in their respective portfolios.

${ }^{5}$ We use a 10-percent random sample of the LPS data when estimating all of our empirical models. The data set is simply too large to use in its entirety from a computational standpoint. However, the main results in the paper are robust to increasing the sample size.
} 
(GSEs), loans securitized by private institutions (private-label loans), as well as loans originated by federal government agencies such as the Federal Housing Authority (FHA) and the Department of Veterans Affairs (VA). The LPS sample used in the analysis is limited to first-lien mortgages that were originated between 2005 and 2007. ${ }^{6}$ We follow these mortgages through April 2011.

The LPS data set contains detailed monthly information on the status of borrowers' repayment behavior. It is possible to tell whether a borrower is current on his or her mortgage or misses a payment and whether a borrower is one payment behind (30-days delinquent), two payments behind (60-days delinquent), or three or more payments behind (90-days delinquent). It is also possible to tell when the lender initiates foreclosure proceedings as well as when the foreclosure process ends and the lender repossesses the property. Unfortunately, there is no indicator for whether the lender grants a delinquent borrower a loan modification, but it is still possible to identify modifications in the LPS sample using an algorithm that we developed in previous work. Basically, the algorithm identifies instances of modification by using changes in the terms of the contracts. ${ }^{7}$

In addition to the LPS data, we use loan-level data from CoreLogic on privately securitized mortgages, which include information on subprime, alt-a, and jumbo prime loans. ${ }^{8}$ Though very similar in content to the LPS data, the CoreLogic data are not representative of the entire U.S. mortgage market because they do not contain loans securitized by the GSEs or loans retained on mortgage originators' balance sheets. Despite this significant drawback, the CoreLogic data do provide a couple of advantages over the LPS data set. First, the time-series coverage is slightly better - CoreLogic has information on private-label mortgages going back to the 1990s. In addition, there is an explicit flag in the data set that indicates when a mortgage has been modified. This information is reported directly by the servicer and provides a nice check on the robustness of the results on modifications obtained indirectly from the LPS sample.

Our analysis focuses on three samples of data. The primary sample is derived from the LPS data set and includes mortgages originated between 2005 and 2007 that became 90days delinquent (at least three missed monthly payments) before March 1, 2009. Outcomes for these mortgages are followed through August 2010, which allows us to observe each loan in the sample for at least 18 months after it became seriously delinquent. ${ }^{9}$ The second

\footnotetext{
${ }^{6}$ LPS added a few large national servicers in January 2005, which created an attrition bias for the mortgage data prior to 2005. When a servicer enters the LPS data set it only provides information on active loans. Thus, if one uses data prior to 2005 from these servicers, it will include only the mortgages that survived until 2005.

${ }^{7}$ For a more detailed explanation see Adelino, Gerardi, and Willen (2009).

${ }^{8}$ Jumbo prime refer to prime mortgages that are larger than the GSE conforming-loan limits.

${ }^{9}$ For the majority of our analysis, we follow loans through only August 2010 in order to avoid contami-
} 
sample is derived from the CoreLogic data set but is otherwise identical to the LPS sample (mortgages originated between 2005 and 2007 that became seriously delinquent before March 1, 2009). This sample, which slightly overlaps with the LPS sample, is used as a check on the representativeness of the results from the LPS sample and a check on the accuracy of the algorithm used to identify modifications in the LPS sample. ${ }^{10}$ Finally, the third sample consists of loans in the CoreLogic data that were originated between 2000 and 2002. These loans are followed and their outcomes observed through 2005. This sample of loans allows us to focus on a period before the current mortgage and foreclosure crisis and to test whether the judicial foreclosure process produced more successful borrower outcomes in "normal times" when defaults and foreclosures were much less widespread.

Table 1 displays summary statistics for the three data samples. The 2005-2010 LPS and CoreLogic samples are broadly similar. The biggest difference between the two samples is the fraction of fixed-rate versus adjustable-rate mortgages. Since adjustable-rate mortgages were the most common type of loan in the subprime and alt-a segments of the market, they make up the vast majority of the CoreLogic data. Data from CoreLogic on loans originated between 2000 and 2002 that became seriously delinquent by 2004 help illustrate the differences in judicial and power-of-sale states before the current mortgage crisis. Loans in this period were more commonly refinance mortgages, secured by single-family, owneroccupied properties. Borrowers tended to have lower FICO scores and defaulted earlier in the life of the loan, but house prices in their neighborhoods were increasing rapidly since the time of origination (an average of 11 percent), and the borrowers were more successful at curing their delinquencies quickly.

The analysis considers two different measures of successful resolutions to serious delinquency: cure and modification. A cure is defined to be an instance in which a borrower in serious delinquency becomes current on the mortgage again and remains in the house or an instance in which the borrower is somehow able to pay off the remaining mortgage balance by selling the property or refinancing the mortgage. ${ }^{11}$ Unfortunately, the LPS data lack sufficient information to distinguish between genuine payoffs of the entire mortgage balance and short sales, transactions in which the lender allows the borrower to sell the property for less than the outstanding balance. Fortunately, the CoreLogic data contain information sufficient to distinguish these two types of sales. CoreLogic reports the loss that investors who own the mortgages experience when the mortgages terminate. In some specifications

nation of our sample from the national "robo-signing" problem and subsequent foreclosure slow-downs and moratoria that impacted judicial states more severely than power-of-sale states.

${ }^{10}$ We were told in conversations with LPS employees that LPS has the weakest coverage for the privatelabel market, which is the only part of the U.S. mortgage market represented in the CoreLogic data.

${ }^{11}$ It is not possible to distinguish between a payoff resulting from a refinance or a sale in the LPS and CoreLogic samples. It is only possible to determine when a borrower paid off his or her current mortgage. 
we show results for short sales as an alternative outcome for delinquent mortgages. ${ }^{12}$

The CoreLogic data also serve as a robustness check for the results on mortgage modifications. A modification in the LPS data set is defined to be an instance in which one of the characteristics of the mortgage changes in a manner not stipulated by the original terms of the contract, while a modification in the CoreLogic data set is an instance in which the servicer reports that the mortgage has been modified and explicitly notes the changes in the mortgage terms. The main empirical analysis compares cumulative cure, foreclosure, and modification rates in judicial versus power-of-sale states over 3-, 6-, 12-, and 18-month horizons following the default. A delinquent borrower is considered to have cured if he or she becomes current on the mortgage or pays off the loan at any point within the given horizon. Thus, even if a borrower becomes current briefly but reverts back to serious delinquency at the end of the horizon, he or she is considered to have cured the delinquency. We also compare cure and modification hazard rates across states with different foreclosure processes to see if delinquent borrowers in judicial states are more likely to cure or renegotiate at any given point in time.

In our full models, we include controls for the change in the borrower's ZIP code-level house price index from origination to the month in which the borrower became seriously delinquent. We also include the change in the county-level unemployment rate during this time, as well as the borrower and loan characteristics displayed in Table 1.

\section{Judicial Intervention}

The original common-law mortgage, the progenitor of almost all mortgages in Anglo-Saxon countries, was a repurchase agreement in which the borrower sold the property to the lender and promised to buy it back by repaying the loan plus interest on an agreed date known as law day. If the borrower failed to appear on law day, the repurchase agreement was void and the lender received clean title to the property, unencumbered by the borrower's repurchase right. English courts of equity viewed this contract as unfair because if the value of the property exceeded the balance on the loan, default would lead to a transfer of wealth from borrower to lender. To remedy this, courts in 16th century England gave the borrower the right to repurchase or redeem the property even if he or she had defaulted on the loan. The borrower could exercise this repurchase right by paying off the loan including interest and any associated costs. The courts understood that there needed to be some limit on the

\footnotetext{
${ }^{12}$ We tested several methods for identifying short sales using the loss information. In this paper a mortgage is considered to have ended in short sale if it is marked as "paid off" in CoreLogic but the mortgage investors experienced a loss greater than 10 percent of the original mortgage principal.
} 
"right of equitable redemption," as it became known, because otherwise the lender could never obtain clean title and therefore the property could never function as collateral for the loan. To solve this issue the courts allowed lenders to petition them to foreclose the borrower's right of equitable redemption - this basic legal concept is the principle behind foreclosure to this day.

The methods of foreclosure have changed, however. Before the 19th century, foreclosure auctions were uncommon. Foreclosures were what are now called "strict," meaning that the lender took possession of the property and it was disposed of at the lender's discretion. However, the courts thought that this was unsatisfactory for largely the same reason the English courts of equity thought that the original medieval mortgage was lacking - the value of the property could still exceed the amount owed and in that case "there is injustice to the mortgagor" (Osborne 1951, 904). The solution to this issue became known in the United States as "foreclosure by sale," whereby a foreclosure is effected by a public auction of the property and the borrower recovers any proceeds in excess of the amount owed to the lender (Osborne 1951, 908). Essentially, the auction provides price discovery.

Two types of foreclosure by sale emerged in U.S. law, and the difference between them is the focus of this section's policy analysis. The first type is foreclosure by judicial sale, in which the lender petitions the court and the court executes the foreclosure by auctioning the property. The alternative approach is that the borrower agrees at origination to give the lender the right to carry out a foreclosure auction in the event of default, a right known as "power of sale" (Osborne 1951, 992). Rare in the early 19th century, power-of-sale foreclosure became more common in the United States over time (Osborne 1951, 993).

The key to the present analysis is that the use of power-of-sale foreclosure varies by state. In some states, such as Massachusetts, it is used almost exclusively, while in other states, such as Connecticut, the law recognizes only judicial foreclosure. However, categorizing states as either "judicial" or "power-of-sale" is not trivial. For starters, the judicial foreclosure option is available in all states, and in some cases lenders might choose to obtain a judgment even when the mortgage deed gives them power of sale. For example, in California a lender which executes a power-of-sale foreclosure loses the right to collect any shortfall between the amount owed by the borrower and the proceeds from the foreclosure auction. More generally, judicial foreclosures are thought to produce clean titles more consistently because defects are less likely. As Nelson and Whitman $(1985,533)$ explain:

There are at least three reasons for this. First, because judicial foreclosure is under court supervision, that very fact will prevent many of the ... defects from arising. ... Second, because judicial foreclosure is an adversary proceeding, the other parties aid the court in calling its attention to potential defects, a second 
type of check on the [lender] not found in power of sale foreclosure. Finally, even if defects go uncorrected, the normal concepts of judicial finality provide the ultimate insulation from attack for a judicial foreclosure decree.

For example, in U.S. Bank v. Ibañez, a recent high-profile Massachusetts lawsuit related to the validity of a foreclosure, the lender sued for a default judgment to remove any possible cloud from the title, despite having already carried out a power-of-sale foreclosure. ${ }^{13}$

To confuse matters even more, granting power of sale does not prevent the borrower from attempting to block the foreclosure in the courts "because a mortgagor has the right, based on either common law or statute, to bring suit to enjoin the foreclosure sale." ${ }^{14}$ Rao and Walsh $(2009,11)$ argue, however, that such protection is minimal:

The homeowner will need to satisfy the demanding pleading and proof requirements which courts impose before issuing injunctions, making it virtually impossible to obtain this relief without the assistance of an attorney.

At the same time, the protections afforded by the judicial procedure are limited. The National Consumer Law Center (NCLC) considers judicial states to be those in which "the lender must file an action in court ...to obtain a judicial decree authorizing a foreclosure sale" and that "[g]enerally ... the lender must prove that there is a valid mortgage between the parties, that the borrower is in default of the mortgage, and that the proper procedure has been followed" (National Consumer Law Center 2010, 104). If the borrower wants to argue, for example, that the loan was predatory, there is limited scope to do so in a standard judicial proceeding.

Many researchers have previously attempted to categorize states as judicial or power-ofsale but, consistent with our claim that the distinction is ambiguous at the state level, no two of these lists are exactly the same. Some are clearly erroneous, including many of the lists available online, such as RealtyTrac and Foreclosures.com, which include many obvious and blatant errors. ${ }^{15}$ However, it is accurate to say that for most states the foreclosure process is almost always either power-of-sale or judicial, and most categorizations largely coincide. The assignment used in this paper comes from Rao and Walsh (2009), two researchers at the NCLC. In addition, we use the list in a standard legal treatise by Nelson and Whitman (2007), which has some minor differences with the NCLC list. ${ }^{16}$

\footnotetext{
${ }^{13}$ The case is U.S. Bank National Association, trustee, vs. Antonio Ibañez (and a consolidated case), 458 Mass. 637 (2011).

${ }^{14}$ Nelson and Whitman $(1985,569)$, footnote omitted.

${ }^{15}$ RealtyTrac, for example, lists Massachusetts as having "deeds of trust," a form of security interest that does not exist in the state.

${ }^{16}$ The difference in the list is that Rao and Walsh (2009) classify Arkansas, Missouri, Nebraska and New
} 
The conventional wisdom is that judicial review slows down the foreclosure processand the data confirm this fact. However, estimating foreclosure timelines directly is difficult because of severe right-censoring problems. Cordell and Shenoy (2011), for example, show that the average foreclosure in New York occurred 20 months after it was initiated; but the vast majority of foreclosures in Cordell and Shenoy's sample period are incomplete (that is, are right-censored), meaning that the expected time to foreclosure is far longer than 20 months. ${ }^{17}$ To deal with the censoring problem, we measure the monthly hazards of foreclosure for borrowers who never cure and use those hazards to calculate the cumulative likelihood of foreclosure. Table 2 reports two statistics: the foreclosure half-life, which is the number of months until 50 percent of foreclosures are complete, and the percent of foreclosures completed within 36 months. Both statistics are calculated from the time of the first 90-day delinquency. The results show wide variation in foreclosure timelines. At one extreme are states such as Alaska and Michigan, in which lenders complete half of all foreclosures within nine months. At the other end of the spectrum is New York, in which almost three-quarters of foreclosures are still pending after 36 months. Table 2 illustrates that judicial review severely retards the foreclosure process. Foreclosure half-lives exceed 36 months in 15 of the 18 judicial states (83 percent), but do so in only 7 of the 33 power-of-sale states (21 percent). There is wide variation within regimes, however, with some short judicial timelines (such as Kansas) and some exceptionally long power-of-sale timelines (including the District of Columbia and New Mexico).

In the wake of the foreclosure crisis, Rao and Walsh (2009) and others have argued for the wholesale elimination of power-of-sale foreclosure, and several states legislatures, including those of Massachusetts and Virginia, have considered bills to require judicial foreclosure. Rao and Walsh $(2009$, 11) make their case partly on constitutional grounds, saying that "[a] fundamental due process protection is the 'opportunity to present objections' to an impartial decision-maker before an individual's property can be taken away." Indeed, jurists have debated the constitutionality of power-of-sale (see Nelson and Whitman 1985, section 7.25). But Rao and Walsh $(2009,11)$ also make a more practical case for judicial foreclosure,

Mexico as power-of-sale and Nelson and Whitman (2007) do not. The empirical results are not sensitive to this distinction.

${ }^{17}$ Cordell and Shenoy $(2011,8)$ examine the involuntary termination of over three million mortgages in the LPS data set, dating back to 1998; they find that the foreclosure process takes an average of 532 days in judicial states, compared to 369 days in power-of-sale states. This time period is measured from the initiation of foreclosure proceedings to the date the lender takes ownership or sells the property directly to a new buyer. The delay results in greater foregone interest for mortgage holders in judicial states, which Cordell and Shenoy $(2011,14)$ estimate would be an additional 2.85 percent of the principal balance. However, because the authors investigate only loans that actually terminate, they do not address whether longer foreclosure timelines enable delinquent borrowers to achieve better outcomes, such as curing delinquencies or obtaining mortgage modifications. 
citing an example of a borrower and lender clearly victimized by an incompetent and corrupt mortgage servicer.

Essentially, the question of the value of judicial foreclosure is, like many public policy questions, a tradeoff between two errors: failing to assist someone who would gain from intervention and providing costly help to someone who would not. In this case, the former problem is foregoing a judicial proceeding for a borrower who would be helped and the latter is intervening on behalf of a borrower who has no hope of curing his or her default. Clearly the NCLC researchers believe that failing to assist is the main, or perhaps only, concern, but their anecdotal evidence does not provide any sense of the relative size of the two problems. Our empirical analysis provides a more rigorous test of this issue and addresses the tradeoff that many, including the NCLC researchers, have failed to consider.

\subsection{Measuring the Effects of Judicial Foreclosure}

To measure the effect of judicial versus power-of-sale, four different outcomes are considered for a borrower who is seriously delinquent on his or her mortgage: cure, modification, foreclosure, and persistent delinquency. A cured mortgage is defined as a case in which the lender identifies a loan as current at some point after the serious delinquency, or a case in which a seriously delinquent borrower repays the loan in full. A modification is identified as a loan for which the lender changes one or more of the original contract terms to allow the borrower to repay more easily. A foreclosure is self-explanatory, while a persistently delinquent loan is defined as a seriously delinquent mortgage for which the borrower has not cured and the lender has not initiated foreclosure proceedings.

The definitions appear simple, but complexity emerges along several dimensions. First, modifications and cures are not mutually exclusive and, in fact, a modification is basically a type of cure. In addition to changing the terms of the loan going forward by, for example, reducing payments or principal owed, a modification almost always involves some adjustment to cover the arrears and fees accrued during the delinquency spell. Typically the lender will add any missed payments to the loan's principal balance and thus, from an accounting standpoint, the borrower has made all payments due on the loan to date. ${ }^{18}$ While it is true that almost all modifications lead to initial (though not necessarily permanent) cures, it is not true that almost all cures stem from modifications. As Adelino, Gerardi, and Willen (2009) show, many cures occur immediately after a borrower becomes seriously delinquent and thus are very unlikely to involve assistance from the lender.

\footnotetext{
${ }^{18}$ In other words, one can view the addition to the balance as an additional loan to the borrower, which the borrower uses to pay off the arrears.
} 
At any point in time after the start of a delinquency spell, the outcomes of cure, foreclosure, and persistent delinquency are mutually exclusive. However, over time, the relationship between the three outcomes becomes more complex. It is possible, but extremely rare, for a property that has completed the foreclosure process to cure or to return to a state of persistent delinquency. As a result, the terminal state of foreclosure is defined as a case in which a lender reports a property as real estate owned (REO), meaning that it is owned by the bank, or reports that a property is "liquidated," meaning that the lender has sold the property (either out of REO or at the foreclosure auction). Cured loans, at the other extreme, often transition back to persistent delinquency and to foreclosure. However, in our analysis cure is treated as an absorbing state - once a loan cures, it is viewed as having cured for all future observations. The logic in making this assumption is that any subsequent default after the cure likely stems from some subsequent event. To the extent that the purpose of policy is to facilitate cure rather than prevent subsequent distress, these subsequent events confound the measurement of policy effectiveness. Persistently delinquent borrowers almost always transition into cure or foreclosure but, as the name suggests, a delinquent state can persist for enormous periods of time. For example, the LPS sample includes borrowers who have been delinquent for 72 continuous months and counting. It also includes delinquency spells that cured after 65 months or terminated in foreclosure after 69 months. There are 11,000 loans in the 10-percent random sample with delinquency spells exceeding 36 months, some 1,700 with spells longer than 48 months, and 170 with spells over 60 months. Not surprisingly, most of these exceptionally long delinquencies occur in judicial states.

How do outcomes for seriously delinquent loans differ across power-of-sale and judicial states? According to the proponents of judicial foreclosure, we would expect a judicial process to be associated with lower foreclosure rates and higher modification and cure rates. However, the data support only the first of those claims. Table 3 reports the cumulative incidence of our different outcomes at various horizons after the start of a serious delinquency spell. ${ }^{19}$ The table shows that at every horizon foreclosure rates are higher for borrowers in power-of-sale states, where more than 19 out of 100 borrowers have already lost their homes six months after becoming seriously delinquent, as compared to fewer than 3 out of 100 in judicial states. After six months, the gap shrinks in relative terms as lenders ramp up foreclosures in judicial states, but in absolute terms, it is still the case that in judicial states almost 20 fewer borrowers per 100 have lost their homes 18 months after the beginning of a delinquency spell.

While judicial foreclosure successfully reduces the likelihood of foreclosure, that differ-

\footnotetext{
${ }^{19} \mathrm{~A}$ delinquency spell begins the first time the borrower becomes 90 -days delinquent. Including subsequent delinquencies in the analysis does not alter our findings.
} 
ence is not offset by an increase in cures but rather by an increase in the ranks of persistently delinquent borrowers. As Table 3 shows, there is little difference between the fraction of borrowers who cure in power-of-sale states compared to judicial states. In fact, when we control for differences in observable loan and borrower characteristics (in a manner described below), after 18 months the cure rate is actually significantly higher (by over 3 percentage points) in power-of-sale states. This finding of similar cure rates results from lower foreclosure rates in judicial states leading to more persistent delinquencies. According to Table 3, almost half of the borrowers in judicial states still own their homes 18 months after becoming delinquent, having made no payments over the entire period, as compared to a little over one quarter in power-of-sale states.

Finally, Table 3 shows that the legal regime has little effect on the likelihood that a borrower receives a loan modification. To the extent that there are differences, modification rates are higher in power-of-sale states. After six months, 8.8 percent of borrowers in judicial states have received modifications, compared to 10.3 percent in power-of-sale states. This small difference persists over time, as modification rates are approximately 2 percentage points higher in power-of-sale states 18 months after serious delinquency. While the statistics in Table 3 are derived from the 2005-2010 LPS sample, in which modifications are imputed, the patterns are very similar using the 2005-2010 CoreLogic sample, in which the data provider specifically flags loan modifications. Unfortunately, modification data are not available for the CoreLogic sample containing borrowers who became seriously delinquent in 2000-2004.

Differences between the cumulative incidences of loan outcomes between power-of-sale and judicial states are systematically analyzed by estimating logit regressions over the horizons listed in Table 3. As shown in Table 1, seriously delinquent mortgages in judicial states are somewhat different, on average, than loans in power-of-sale states. Namely, borrowers in judicial states tend to have somewhat lower average FICO scores at origination (648 as compared to 654 in power-of-sale states, according to LPS), their loans are less likely to be secured by single-family homes (78 percent as compared to 87 percent), and area house prices fell less in their communities since their loans were originated (9 percent as compared to 13 percent). While these statistics differ somewhat for the CoreLogic samples, the relationships are broadly similar. These and other differences in mortgage characteristicssuch as whether the mortgage is a refinance of a previous loan, whether the borrower is an occupant-owner, and whether the mortgage has a fixed or adjustable rate - may impact a delinquent borrower's ability to cure or negotiate a mortgage modification. In the regressions, we control for such characteristics to account for these influences. ${ }^{20}$ Table 4 displays

\footnotetext{
${ }^{20}$ Unfortunately, not all mortgages have a full set of covariates in the data sets. The implications of these
} 
the logit estimation results in the form of odds-ratios for the 2005-2010 LPS sample for the 12-month horizon. In Table 3, we use the logit estimates to calculate the cumulative effect of judicial foreclosure proceedings on borrower outcomes at horizons of $3,6,12$, and 18 months after borrowers become seriously delinquent. ${ }^{21}$ Within each panel of Table 3 the columns marked "With Controls" show the difference in the cumulative incidence of cure estimated with the logit model for a set of prototypical borrowers of fixed-rate mortgages, secured by owner-occupied single-family properties, with mean FICO scores, LTV ratios, area house price change, and time elapsed between origination and delinquency.

The logit estimation results in Table 4 consistently show little evidence that judicial foreclosure statutes result in better borrower outcomes. The odds ratios associated with the judicial indicator in Table 4 are significant at the 0.1 percent level, but are less than 1.0 in magnitude for each outcome, indicating that borrowers in judicial states are less likely to cure their mortgage delinquencies and negotiate modifications than borrowers in power-ofsale states, controlling for borrower and loan characteristics. Twelve months after borrowers become seriously delinquent, those in judicial states are about 0.86 times as likely to have cured than are those in power-of-sale states. The difference in cumulative modification rates, as shown in Table 4, is similar. Again, borrowers in judicial states appear to fare worse-borrowers in judicial states are slightly less than 0.85 times as likely to have received a mortgage modification over each time horizon. As with cure rates, while this difference between borrowers in judicial and power-of-sale states is not large it is statistically significant and seems relatively stable across the various time horizons. Cumulative foreclosures are much lower 12 months after default for borrowers in judicial states. In fact, such borrowers are only 0.28 times as likely as borrowers in power-of-sale states to have lost their properties to foreclosure. However, as we demonstrate below, foreclosure rates in judicial states catch up with power-of-sale states over time. Ultimately, there is no net difference between the two types of states; borrowers in judicial states simply experience longer foreclosure timelines, not lower incidences of foreclosure. ${ }^{22}$

It is important to note that two features of the data complicate the analysis. First, about half of the loans in the sample lack information on at least one of the covariates included in the logit regressions. Because these loans and the associated borrowers may be different in some way from those with full information, the sensitivity of the results to the omission of these loans is examined. To do this, the logit models are estimated in three ways: first

\footnotetext{
missing values are discussed below.

${ }^{21}$ The estimated coefficients that are used for these calculations, for the other data samples, and for other horizons are not shown for space considerations, but are available in the online appendix at https://sites.google.com/site/paulwillenshomepage/Home/a/rtc_internet_appendix.pdf Additional results are available by request.

${ }^{22} \mathrm{~A}$ full set of results for each outcome at the four time horizons is available in the online appendix.
} 
including the full sample and estimating a baseline model, next re-estimating the baseline model with the restricted sample of loans for which there are a full set of covariates, and finally estimating the full model with the restricted sample. ${ }^{23}$

The impact of right-censoring (experienced by a small percentage of loans which are transferred to servicers that do not report to LPS) is also discussed more thoroughly in the online appendix, in which we compare specifications that consider censored loans to be persistently delinquent (and not modified) with specifications that consider the loans to be cured, censored, or modified. Our results are robust to these other methods of treating censored borrowers. ${ }^{24}$

\subsection{Foreclosure and Cure Hazards}

For several reasons, we now turn to an alternative method to analyze borrower outcomes by looking at the monthly hazard of foreclosure and cure. At a technical level, hazards, unlike the cumulative-incidence functions above, control for right censoring, which is a significant issue in the data. Almost 12 percent of loans from the CoreLogic sample that became seriously delinquent between January 2005 and February 2009 were still delinquent as of April 2011. The censoring issue is even more severe in the LPS sample, as about 14 percent are still delinquent at the end of the period, while an additional 6 percent have been transferred to mortgage servicers that do not report to LPS.

The hazards also provide insights that the cumulative-incidence functions cannot. First, the hazards allow us to overcome, to a degree, the fact that we only observe a relatively short time series for the LPS data. Second, the evolution of the monthly hazards sheds

\footnotetext{
${ }^{23}$ Full results can be found in the online appendix. Despite the large difference in the sizes of the full sample and subsample with complete covariates, our results are highly robust. A summary of this robustness can be found in Tables A-1, A-2, and A-3 in the online appendix by comparing the raw outcomes across the full and estimation samples. For clarity, we work with the estimation (that is, restricted) sample in the rest of our analyses and robustness checks.

${ }^{24}$ These tables also attempt to distinguish how strategic defaults may influence our results. We exclude borrowers who are most likely to have defaulted strategically - those for whom the delinquency spell we study is their first serious delinquency and those who miss three consecutive payments at the beginning of their delinquency spells. While this behavior may be thought of as more common in judicial states, and thus may make those states appear worse in terms of cures and modifications, in fact excluding these borrowers has no effect on our findings about cure rates in Table A-1 and even increases the gap between power-of-sale and judicial states in terms of modifications. Therefore, we do not think our results in favor of power-of-sale foreclosure are driven by strategic defaulters. We further check our results using the CoreLogic data set, which has information on investor losses and fewer right-censored loans, allowing us to restrict our definition of "cures" to exclude short sales. As shown in Table A-1, our results are robust in the 2005-2010 CoreLogic sample for cure rates, although there is some evidence that the cure rates are influenced by short sales; by removing short sales as a form of cure, judicial states appear to have somewhat higher cure rates than power-of-sale states, about 2 to 3 percentage points at each horizon. Our results on mortgage modifications are also similar when we use the CoreLogic data, as shown in A-3. We also examine the types and number of modifications made to loans; full results can be found in the online appendix.
} 
light on competing explanations for the minimal effect of judicial foreclosure procedures on cures.

Before estimating the hazards, it is useful to note what information the cumulativeincidence functions convey about them. Essentially, taken together a higher cumulative foreclosure incidence and the same cumulative cure incidence imply that the instantaneous cure hazard is higher in power-of-sale states. Intuitively, delaying the foreclosure process gives borrowers more opportunities to cure, so if the hazard - the per-period conditional probability of curing - were higher, then more borrowers would be expected to cure in judicial states. However, Table 3 shows that cumulative cure rates are slightly lower in judicial states (controlling for observable characteristics), which implies that the hazards must also be lower.

These hazards are surprising because they show that the ostensible reasons for judicial foreclosure - lower foreclosure rates and higher cure and modification rates - are invalid. At the very least, the judicial process is supposed to give borrowers more chances to cure their delinquencies or negotiate modifications. In other words, even if cure and modification hazards are the same in judicial and power-of-sale states, the longer foreclosure timeline in judicial states should translate into more of each of the two outcomes. In addition, proponents suggest that the cure and modification hazards should actually be higher in judicial states as the increased time cost of foreclosure tilts the balance in favor of renegotiation. But as seen in Table 3, we have found exactly the opposite.

To explain the higher cure hazards in power-of-sale states, two natural candidates emerge. The first is that knowledge of the process leads to some self-selection among borrowers into serious delinquency. For example, in judicial states the prospect of a longer rent-free period might induce more instances of "strategic delinquency," borrowers who decide to default despite being able to afford their mortgage payments and therefore choose ex ante not to cure. The second possibility is that the increased foreclosure hazard itself induces some selection within the existing pool of delinquent borrowers by, for example, removing borrowers less likely to cure.

We now turn to the actual hazards. The top and bottom panels of Figure 1 show the unconditional monthly cure and foreclosure hazards across foreclosure regimes for the 20052010 LPS sample and the 2000-2005 CoreLogic samples, respectively. As expected, Figure 1 shows both higher foreclosure and cure hazards in power-of-sale states. In both the LPS and CoreLogic samples, cure hazards in the initial few months of delinquency are nearly identical for borrowers in judicial and power-of-sale states, though these hazards quickly diverge around three months, the same time that foreclosures spike in power-of-sale states.

As promised, we can use the hazards to deal with the eccentricities of our sample. Specif- 
ically, we draw attention to the fact that most borrower time-series in the LPS sample are right-censored - we call these borrowers "persistently delinquent." Whether those borrowers cure or lose their homes to foreclosure has significant policy implications: if most cure, then in the long run a big gap will emerge in favor of judicial states because at every horizon there are more persistently delinquent borrowers in judicial states. To address this question, we model the hazards using a multinomial logit model which allows us to control for observable differences in mortgage and borrower characteristics. The multinomial logit allows us to perform a competing-risks analysis; it follows delinquent borrowers each month from the time they become seriously delinquent to the month that they cure, lose the property to foreclosure, or are right-censored in delinquency. Our preferred specification incorporates the length of the delinquency spell using indicator variables for each of the first 24 months and then a second-order polynomial for months 24 through 36 . The odds ratios for the variable of interest-Judicial - and other substantive covariates are displayed in Table 5. ${ }^{25}$

Using the competing-risks model, we can construct the predicted cumulative-incidence function for a prototypical borrower over a long horizon. Figure 2 shows how the gaps between judicial and power-of-sale states in the cumulative hazards changes as the delinquency spell continues for both our baseline 2005-2010 LPS sample and for the 2000-2005 CoreLogic sample. Keep in mind that, in the long run, all delinquent borrowers must either cure or lose their homes. From the cumulative-incidence functions discussed above, we know that at 18 months there is no difference in the number of cures but a big difference in the number of foreclosures across the two regimes, so either the foreclosure gap between judicial and power-of-sale states must shrink or the cure gap must explode. What Figure 2 shows is that the former is the case. In the CoreLogic sample, a 12 percentage-point gap in foreclosure rates at month 9 shrinks to less than 4 percentage points by month 24 . Even with the short time-series in the LPS sample, we can see an even more dramatic transition as an almost 20 percentage-point gap at month 12 falls to less than 10 percentage points by month 36. Interestingly, when we extend the sample to include the 2010-2011 "robosigning" episode, which temporarily halted foreclosure proceedings in judicial states, we see a dramatic slowdown in convergence.

As mentioned above, the hazards also help us to understand how the foreclosure process affects cure behavior. The fact that the cure hazards are indistinguishable across regimes for the first three months weighs against any story of selection prior to seriously delinquency, including the strategic delinquency example discussed above. If borrowers who default

\footnotetext{
${ }^{25}$ We achieve similar results, though with poorer fit, by specifying time simply as a higher-order polynomial on months. We also fitted the model using a general specification of time (with dummies for each of the 36 months studied), but the loss of degrees of freedom was not justified by the improvements in model fit.
} 
in judicial states are systematically different from borrowers who default in power-of-sale states, it is difficult to explain why differences in their behavior do not emerge until the fourth month.

But a deeper insight comes from the fact that the spike in foreclosures in power-of-sale states coincides with the emergence of a gap in cure rates. This fact suggests that it is the foreclosure activity which generates selection in the existing pool of delinquent borrowers across regimes. To illustrate this point, we propose a simple model with a continuum of borrowers divided into two types $i \in\{g, b\}$ for good and bad, respectively. Good types are more likely to cure at all times $t$ so $c_{t}^{g}>c_{t}^{b}$ where $c_{t}^{i}$ is the probability of cure at time $t$ for type $i$. Lenders are less likely to foreclose each period on good types so that $f_{t}^{b}>f_{t}^{g}$, where $f_{t}^{i}$ is the probability of foreclosure at time $t$ for type $i$, either because the lender knows the borrower's type and weighs the higher likelihood of repayment resulting from forbearance or because borrowers more likely to cure are more likely to fight foreclosure through the legal system. At time $t$ the share of good borrowers is $\sigma_{t}$, meaning that the cure and foreclosure hazards in the population are $c_{t}=\sigma_{t} c_{t}^{g}+\left(1-\sigma_{t}\right) c_{t}^{b}$ and $f_{t}=\sigma_{t} f_{t}^{g}+\left(1-\sigma_{t}\right) f_{t}^{b}$, respectively. Thus, tracing the behavior of the hazards over time essentially amounts to following $\sigma_{t}$. Simple algebra shows that the share of good borrowers $\sigma_{t}$ evolves according to the expression

$$
\sigma_{t+1}=\frac{\sigma_{t}\left(1-f_{t}^{g}-c_{t}^{g}\right)}{\sigma_{t}\left(1-f_{t}^{g}-c_{t}^{g}\right)+\left(1-\sigma_{t}\right)\left(1-f_{t}^{b}-c_{t}^{b}\right)}
$$

or

$$
\frac{\sigma_{t+1}}{\sigma_{t}}=\left[\sigma_{t}+\left(1-\sigma_{t}\right) \cdot \frac{1-f_{t}^{b}-c_{t}^{b}}{1-f_{t}^{g}-c_{t}^{g}}\right]^{-1} .
$$

To illustrate the effect of policy on the distribution of borrower types, assume that the survival probability $1-f_{t}^{i}-c_{t}^{i}$ (that is, the probability of remaining in delinquency) is the same for both types, meaning that the lower cure rate for bad types exactly offsets their higher foreclosure rates. Equation (1) shows that assuming equal survival probabilities means that $\sigma_{t}$ is constant over time. Now, assume that policymakers are able to affect the foreclosure hazards in a proportional manner, which is modeled by multiplying both foreclosure hazards by $\phi$ :

$$
\frac{\sigma_{t+1}}{\sigma_{t}}=\left[\sigma_{t}+\left(1-\sigma_{t}\right) \cdot \frac{1-\phi f_{t}^{b}-c_{t}^{b}}{1-\phi f_{t}^{g}-c_{t}^{g}}\right]^{-1} .
$$

Under the assumption of equal survival probabilities, $\phi=1$. Supposing that $\phi$ is increased, 
what happens to the evolution of $\sigma_{t}$ ? The derivative of the growth rate of $\sigma_{t}$ is given by:

$$
\left.\frac{\partial \frac{\sigma_{t+1}}{\partial t}}{\partial \phi}\right|_{c_{t}^{b}+f_{t}^{b}=c_{t}^{g}+f_{t}^{g}}=\left(1-\sigma_{t}\right)\left[\frac{f_{t}^{b}-f_{t}^{g}}{1-f_{t}^{g}-c_{t}^{g}}\right]>0 .
$$

Equation (3) shows that increasing $\phi$ for one period increases the share of good borrowers the next period. Reverting to the baseline $\phi$ means that $\sigma$ will remain constant but the increase in the share of good borrowers in the population persists. In other words, a one-time proportional increase in the foreclosure probability for both types leads to a permanent increase in the share of good types in the borrower population. The intuition here is straightforward: an increase in the probability of foreclosure affects bad types more than good types and improves the remaining distribution of delinquent borrowers.

Returning to Figure 1, we see that the model generates a plausible explanation for the key stylized facts from the hazard picture. Early on in the delinquency, before foreclosures have started, cure rates across the foreclosure regimes are very similar; in the model, this means that the distribution of good and bad types is roughly equal. The gap in cure rates between judicial and power-of-sale states emerges only when lenders start foreclosing and, according to the theory, the spike in foreclosure rates in power-of-sale states permanently changes the distribution of borrowers, leading to persistently higher instantaneous cure rates in power-of-sale states. This provides theoretical justification for the claim that the judicial process indiscriminately blocks efficient foreclosures.

\section{The Massachusetts Right-to-cure Law}

In November 2007, Massachusetts legislators passed a law that provided a 90-day right-tocure period for borrowers whose lenders initiated foreclosure proceedings on or after May 1, $2008 .^{26}$ Right-to-cure laws temporarily stop the foreclosure clock and are aimed at helping borrowers self-cure or obtain modifications by providing them with more time during which to work with lenders and assemble required documentation. According to a statement by the Massachusetts Attorney General just before the implementation of the 90-day right-to-cure law:

We expect that lenders and servicers will use this cooling off period to engage borrowers, find solutions, and achieve loan modifications that make sense for

\footnotetext{
${ }^{26}$ The right-to-cure period was available for only those borrowers who occupied the properties as their principal residences, not investors or vacation-home owners. The law also allowed the right-to-cure period to be applied only once in a five-year period, so borrowers who cure and re-default within five years would not receive the protection again.
} 
homeowners, the Commonwealth, and the lenders and investors themselves. ... For months, we have heard the major subprime lenders and servicers talk about loan modifications, but these words have not translated to real loan restructuring on the scale that is necessary to staunch the tide of foreclosures. ${ }^{27}$

In this section we measure the impact of the Massachusetts right-to-cure law on the outcomes of delinquent mortgages. There are several advantages to focusing on a specific policy, compared to our above analysis examining broad-based differences in statelevel foreclosure regulations. Perhaps the most important advantage is the ability to use a difference-in-differences identification strategy that compares changes in mortgage outcomes in Massachusetts before and after the implementation of the right-to-cure law with changes in outcomes in neighboring states that did not adopt the law. Compared to the preceding cross-sectional analysis of mortgage outcomes in judicial and power-of-sale states, this difference-in-differences strategy is less likely to suffer from simultaneity concerns.

\subsection{Foreclosures and the Right to Cure in Massachusetts and Neighboring States}

We use LPS data on the performance of individual first-lien residential mortgages originated between 2005 and 2007 in Massachusetts, Connecticut, New Hampshire, and Rhode Island. We select borrowers who became 90-days delinquent in the months just before and after May 2008, when Massachusetts implemented the right-to-cure law. We restrict the sample to oneto-four family houses and condominiums, since these are the properties covered by the law. Table 6 displays summary statistics for various characteristics of delinquent borrowers and mortgages at the time of loan origination, with columns for Massachusetts, the individual comparison states, and the three comparison states pooled together. In most respects, borrowers in the different states are comparable on observable characteristics. Massachusetts borrowers have slightly lower loan-to-value ratios and slightly higher credit scores than the average non-Massachusetts borrower. In the sample, Massachusetts borrowers are also somewhat more likely to have adjustable-rate mortgages. When comparing the earlier and later delinquency cohorts, the later cohorts both in and out of Massachusetts appear slightly better in these same underwriting and loan characteristics.

Foreclosure indicators show that foreclosure starts and completed foreclosures fell in Massachusetts after the right-to-cure policy took effect. Foreclosure petitions (signals of the

\footnotetext{
${ }^{27}$ Office of the Attorney General, "Governor Deval Patrick, Attorney General Martha Coakley Notify Consumers of New Law Set to Take Effect May 1st," Press Release, April 30, 2008 (internal quotations omitted).
} 
start of foreclosure proceedings) and foreclosure deeds (markers of the end of the foreclosure process) rose rapidly in Massachusetts and neighboring states in 2007 and early 2008. In Figure 3 the upper panel shows that foreclosure petitions in Massachusetts rose from approximately 2,000 per month in early 2007 to 3,000 per month in early 2008. Petitions decreased dramatically after the introduction of the 90-day right-to-cure law in Massachusetts but returned to high levels in September 2008, which appears to show that the right-tocure law temporarily suspended foreclosures and may have reduced subsequent foreclosure rates somewhat. The lower panel of Figure 3 shows that foreclosure deeds also climbed significantly prior to the imposition of the law and fell afterwards. What accounts for the spike in foreclosure deeds is unclear, but it is unlikely to be related to the law, because the petitions corresponding to the foreclosures completed before and up to three months after the imposition of the law predate the imposition of the law and were therefore not subject to its requirements. It is easy to see why lenders would rush to file petitions prior to the law but there was little reason to complete foreclosures at that time.

When Massachusetts adopted the 90-day right-to-cure law, none of the surrounding states included in the analysis (Connecticut, New Hampshire, and Rhode Island) had adopted similar policies or other major changes in their foreclosure laws. Neither were there other major policy changes influencing foreclosure rates in Massachusetts, nor other changes in economic conditions that would have influenced Massachusetts alone. Thus, the institution of the 90-day right-to-cure law in Massachusetts serves as a natural experiment to assess how cure and modification rates changed following a state-mandated delay in the foreclosure timeline.

In Table 6 the "Outcomes" section displays the percentage of borrowers that cured their delinquencies or received modifications of their loan terms six months after becoming seriously delinquent. Six-month cure rates in Massachusetts fell by 3 percentage points for loans affected by the right-to-cure policy, while the same cure rates in the other states fell by only 1 percentage point on average. On average, cure rates were 5 to 7 percentage points lower in Massachusetts than in the other states. Modification rates rose in Massachusetts after the right-to-cure law was implemented, but they also rose by about the same amount in the surrounding states. Therefore these preliminary descriptive statistics seem to suggest that the right-to-cure law did not improve outcomes for Massachusetts borrowers in serious default. ${ }^{28}$ We now turn to a more formal analysis to assess the impact of the Massachusetts right-to-cure law on the outcomes of delinquent mortgages.

\footnotetext{
${ }^{28}$ Raw statistics for 3-, 12-, and 18-month cure and modification rates show similar patterns and are available from the authors upon request.
} 


\subsection{Empirical Strategy}

To assess the impact of the 90-day right-to-cure law in Massachusetts, we use the LPS data to estimate a difference-in-differences specification for the probability that borrowers cure their mortgage delinquencies or successfully renegotiate with their lenders to obtain mortgage modifications. We track the outcomes for borrowers in Massachusetts, Connecticut, New Hampshire, and Rhode Island, both before and after the law took effect on May 1, 2008. In most of the analysis, we separate borrowers into two "delinquency cohorts." The first cohort is made up of borrowers who became 90-days delinquent in January, February, or March 2008, and thus were unlikely to receive the 90-day right-to-cure protection; the second cohort is made up of borrowers who became 90-days delinquent in April, May, or June 2008, and thus were likely to have received the right-to-cure protection. ${ }^{29}$ We estimate the effect of the right-to-cure policy using the logistic regression

$$
\operatorname{Prob}\left(y_{i}=1 \mid \text { Delinq }\right)=\frac{1}{1+e^{-\left(\alpha+\beta \cdot\left(\mathrm{MA}_{i} \cdot \mathrm{RTC}_{i}\right)+\delta \cdot \mathrm{MA}_{i}+\theta \cdot \mathrm{RTC}_{i}+\chi \cdot X_{i}+v_{i}\right)}},
$$

where the dependent variable, $y_{i}$, is a dichotomous variable that indicates whether borrower $i$ has cured his or her delinquency, and MA is a dichotomous variable that indicates if borrower $i$ 's property is in Massachusetts. We use the date when the borrower became 90days delinquent as the source of exogenous variation in whether a borrower was protected by the right-to-cure policy. Borrowers who became 90-days delinquent in April 2008 made their last mortgage payments in December 2007. After a borrower becomes 60- to 90-days delinquent, most lenders issue a notice of default in which they state their intention to demand full repayment of the loan if the borrower does not immediately become currentan action known as "accelerating" the mortgage. Assuming that an additional 30 days elapse before the lender officially accelerates the mortgage, it is safe to assume that a borrower who became 90-days delinquent in April 2008 would have received the 90-day right-to-cure period, which applied to loans that had not been accelerated prior to May 1. In contrast, borrowers who became 90-days delinquent before April 1 likely did not receive the 90-day right-to-cure period. ${ }^{30}$ In Equation (4), RTC is a dichotomous variable indicating if the borrower is in the cohort of borrowers who became delinquent during April-June 2008, which would make the borrower eligible for the right-to-cure protection.

The exact time at which a loan becomes 90-days delinquent is arguably exogenous, since

\footnotetext{
${ }^{29}$ Below, we expand our analysis to consider a wider window on either side of the policy change. We also test whether including the March defaulters in the right-to-cure cohort affects the results, in case these borrowers actually received the right-to-cure protection, but this does not change our findings.

${ }^{30}$ Information on the exact date of a given loan's acceleration is not public record and is not included in the data set we use. Because of this, we must use the timing of the delinquency as a proxy for whether the borrowers received the right-to-cure or were subject to the original, expedited foreclosure process.
} 
within a narrow window of time (six months in this study), it is probably random as to whether borrowers default on one side of the cut-off or the other. Presumably, financially distressed borrowers have little control over precisely when they stop making mortgage payments, and even if a decision could be made about when to default, it would have been made at least four months prior to the implementation of the right-to-cure policy. As we will show later, there is little evidence that Massachusetts borrowers "crossed over" to the right-to-cure delinquency cohort in order to receive the 90-day protection.

The parameter of interest in Equation (4) is $\beta$, which captures the impact of receiving the 90-day right-to-cure protection in Massachusetts. Since borrower traits and loan characteristics also influence a delinquent borrower's ability to cure, a vector of these characteristics, $\chi$, is included in the estimation. We estimate the logistic regression models separately for cures and modifications, and examine mortgage outcomes at four intervals: 3, 6, 12, and 18 months after the borrower became 90-days delinquent. As in our analysis of judicial and power-of-sale states, a borrower is considered to have cured his or her delinquency if the mortgage is recorded as current at any time during the interval, even if the borrower later redefaults on the mortgage. We hypothesize that differences in outcomes between borrowers who receive and do not receive the right-to-cure protection, if such differences exist, will be strongest for the 3- and 6-month periods. Because the policy only directly impacts the first 90 days after a borrower receives a notice of default, it seems reasonable to expect that any effects of the policy would be attenuated over time.

We identify the treatment effect of the 90-day right-to-cure policy on delinquent Massachusetts borrowers with the difference-in-differences regression specified in Equation (4). The process essentially occurs by comparing two differences. The first difference reflects the change in Massachusetts borrower cure rates from before and after the right to cure took effect. The second difference identifies the change in cure rates during the same period in the neighboring states. Subtracting the second difference from the first yields the final difference - the so-called difference-in-differences - which is an estimate of the causal impact of the right to cure, net of any general trends in cure rates that may have occurred during the time period. We repeat the same procedure to measure the law's effect on modifications.

The appropriateness of this strategy rests on two key assumptions. The first is that borrower outcomes in Connecticut, New Hampshire, and Rhode Island serve as adequate comparison groups for assessing general trends in cures and modifications. While there are small differences in borrower and mortgage attributes across states, as seen in Table 6 and discussed briefly above, the states contain broadly similar characteristics. In addition, there were no changes to foreclosure laws in the three comparison states during the study period, so it seems that these states indeed serve as a useful and appropriate comparison group. 
The second assumption is that trends in cure and modification probabilities over time must be linear within the borrower cohorts. Inspection of the raw cure and modification rates by borrower cohort, located at the bottom of Table 6 , suggests that borrowers in each cohort had similar outcomes in Massachusetts and in the comparison group.

\subsection{Results}

In this section we report the results from estimating Equation (4) for cure and modification, our two mortgage outcomes of interest. Results are reported using short horizons of 3 and 6 months after entering serious delinquency, as well as for longer time horizons of 12 and 18 months. An important point to note before presenting the results is that, as with the LPS data we used in the analysis of judicial and power-of-sale states, there is a right-censoring issue in the data: approximately 4 percent of seriously delinquent mortgages are censored by the 18th month, either because they were transferred to different servicers that do not report to LPS or, more rarely, because the existing servicers stopped reporting information on the loans. In the estimation results reported in this section, these censored loans are assumed not to have cured or experienced a modification. As a robustness check, we have estimated all the models in this section in two ways, first by considering all the censored loans as having cured and received a modification, then by considering all the censored loans not to have cured or received a modification. This provides upper and lower bounds for the cure and modification rates. ${ }^{31}$

A second challenge presented by the LPS data set is missing values for covariates. About half the loans lack at least one piece of information on borrower characteristics, mortgage terms, or ZIP code-level change in the house price index since origination. Rather than impute the missing values, we addressed the missing data problem by estimating the logit models in three ways: first with no additional control variables on the full sample of loans that include mortgages with missing information on covariates (the "full sample"); next with no additional control variables on the sample of loans without missing values on covariates (the "restricted sample"); and finally with additional control variables on the restricted sample. Interestingly, the sign and size of the coefficients of interest (those on the state dummies, cohort dummy, and Massachusetts cohort interaction) are not sensitive to the type of specification used or the sample restriction to only those loans with full covariate

\footnotetext{
${ }^{31}$ The lower bound is probably the more accurate number, at least for the cure estimates. Among the censored loans, nearly two-thirds were in foreclosure at their last observation and almost all the remaining one-third were 90-days delinquent but pre-foreclosure. Thus, we chose to assume that censored loans do not cure and are not modified for the results presented in the paper. The two methods, however, generate very similar results; our results hold regardless of how we treat the censored borrowers. When we estimate a hazard model for loan outcomes, we also find similar results.
} 
information. This suggests that observations with missing covariates are not systematically different than observations with full information. Table 7 displays the estimation results for these three samples at the 6-month horizon for both the cure and modification outcomes, respectively. The key odds ratio of interest - the interaction between the Massachusetts indicator and the indicator for the implementation of the right-to-cure law $(\mathrm{MA} \times \mathrm{RTC})$ is less than one but never more than marginally significant in any of the samples for the cure or modification outcome. Thus, the 90-day right-to-cure law does not appear to have had a positive impact on mortgage outcomes for delinquent Massachusetts borrowers at the 6-month horizon. It is notable that, across the region, cures and modifications became more common for borrowers who became seriously delinquent in the second quarter of $2008 .^{32}$ This finding is consistent with previous evidence of increased modification rates over the course of the mortgage crisis (see, for example, Adelino, Gerardi, and Willen 2009). However, it is clear from the results that there was no relative increase in modification rates in Massachusetts compared to neighboring states.

The fitted probabilities of cure and modification are shown in Figure 4 for a prototypical borrower of a fixed-rate purchase mortgage with average LTV (79 percent), FICO score (651), months elapsed between origination and default (18), average decline in ZIP codelevel price index since origination (8.9 percent), and average increase in unemployment rate (0.54 percentage points). As shown in Figure 4, the fitted probability of cure for borrowers in Massachusetts three months after becoming seriously delinquent held steady at about 0.16 after the right-to-cure period was introduced, while in Connecticut the probability of cure rose from 0.18 to $0.21 .^{33}$

Figure 4 further confirms that there has been no economically meaningful change in modification rates in Massachusetts following the implementation of the right-to-cure law. While modification rates were higher in Massachusetts for borrowers who received the right to cure (dashed blue line), the positive difference in modifications was even greater for the comparison cohort of Connecticut borrowers (dashed red line). As with the cure models, greater statistical power is unlikely to change the results because the critical cumulative odds ratio $(\mathrm{MA} \times \mathrm{RTC})$ is less than one for two of the time horizons and approximately one for the most meaningful time horizon, the final period (18 months after the mortgages became seriously delinquent).

\footnotetext{
${ }^{32}$ See the right-to-cure odds ratios in Table 7 and the distance between the solid and dotted lines in Figure 4.

${ }^{33}$ For ease of interpretation, Figure 4 displays only the fitted probabilities for borrowers in Massachusetts and Connecticut. Results for Rhode Island and New Hampshire are available upon request.
} 


\subsection{Robustness Checks}

To be confident that the right-to-cure law improved neither the rates at which Massachusetts borrowers cured nor the rates at which they received modifications, we examined the sensitivity of the results to alternative model specifications and sample definitions. In addition, we examined descriptive statistics to determine if there is evidence that borrowers could "self-select" into the delinquency cohort that received the right-to-cure protection. Below we present the results from different specifications - allowing borrowers with previous delinquencies, adjusting the sizes and definitions of the delinquency cohorts, re-defining the modification outcome to examine whether different types of modifications were made, and examining the potential bias of borrower "self-selection." Finally, we discuss the steps taken to address the largest threat to validity, the difficulty of definitively categorizing Massachusetts borrowers as having received or not received the 90-day right-to-cure period. ${ }^{34}$

Recall that the baseline sample includes borrowers who became seriously delinquent for the first time during January-June 2008. Some borrowers impacted by the implementation of the right-to-cure law may have experienced delinquency previously. Including these borrowers in our sample does not change our results. In order to isolate the impact of the right-to-cure law and avoid complications from borrowers who bounced in and out of delinquency before January 2008, we must still remove any borrowers who had been seriously delinquent in the year leading up to their January-June 2008 delinquency spells. In other words, for this exercise, borrowers who became seriously delinquent in April 2008 could not have been 90 or more days delinquent since April 2007. Notice that this still allows borrowers to be in the sample if they were seriously delinquent in prior years. While this particular group of borrowers (those who were seriously delinquent in the year before January-June 2008) makes up a small portion of the sample and appears equally spread across the states and delinquency cohorts (see "previous 90-day delinquency spell" in Table 6), we decided to exclude them from the models to be sure that they do not drive the results. In the online appendix we display additional results for this restricted sample, although none of the estimates of interest change in any substantive way.

To further test the validity of the results, we adjusted the sizes of the cohorts from three months each to five months each. In other words, the early cohort was extended to include borrowers who became seriously delinquent November 2007-March 2008 and the later cohort was extended to include borrowers who became seriously delinquent AprilAugust 2008. This change increased the sample of borrowers who became delinquent for the first time and which contained complete data on all covariates by about 3,500 mortgages. Increasing the size of the cohorts allows us to test the sensitivity of the findings to borrowers

\footnotetext{
${ }^{34}$ To conserve space, we have placed the tables of these robustness checks in the online appendix.
} 
who became seriously delinquent four to five months before and after the cutoff, which is appealing because the treatment status of these borrowers (whether or not they received the right-to-cure protection) is more certain compared to the borrowers who became seriously delinquent very close to the policy change. ${ }^{35}$ Our substantive findings do not change when we estimate the logit model on the larger cohorts.

Although we have found no evidence of a significant differential change in modification rates in Massachusetts following the introduction of the 90-day right-to-cure period, it could be possible that the types of modifications changed - that is, the distribution of modifications could have shifted to types that are more beneficial for borrowers. In order to investigate this possibility, we estimated separate logit models for each type of modification: interest-rate adjustment, monthly-payment reduction, term extension, principal-balance reduction, and principal-balance increase. The estimation results showed no evidence that any specific type of modification rate changed after the introduction of the right to cure, conditional on controlling for regional changes in modification rates. Finally, we fitted a Poisson model to estimate the number of mortgage modifications that a given loan received, but there was still no evidence of a policy effect in Massachusetts.

Another concern is that financially distressed borrowers in Massachusetts who had no intention of curing their mortgage defaults or seeking modifications may have strategically placed themselves in the cohort that received the right-to-cure protection. Such strategic behavior would attenuate the effect of the right-to-cure policy on mortgage cures and modifications. Homeowners were given significant advance notice that the right-to-cure law would take effect, because Massachusetts Governor Deval Patrick signed the legislation that created it in November 2007. While some forward-looking borrowers may have had the incentive to postpone their defaults in order to slow the foreclosure process and increase the time they could live in their properties rent-free, such a strategy would have required significant advanced planning. Note that a borrower who became 90-days delinquent in April 2008 made his or her last mortgage payment in December 2007. Not only would a borrower have had to meticulously plan the timing of default (and have detailed knowledge of the workings of the foreclosure process), but he or she would have had to possess the financial resources to postpone default. After all, any gain in the time the borrower could live in the home rent-free (perhaps 30 or 60 days) would be partially offset by having to make the additional mortgage payment(s) to postpone default until the right-to-cure law went into effect. Therefore, it seems unlikely that many borrowers would have purposely "crossed over" into the protected cohort. The number of borrowers in the Massachusetts

\footnotetext{
${ }^{35}$ Of course, the tradeoff is that borrowers who became seriously delinquent in November 2007 may be different in unobserved ways from borrowers who became seriously delinquent in June 2008.
} 
cohort increases somewhat after the introduction of the right to cure, though the same can be said of each of the three other states. Given that the number and characteristics of borrowers in the two Massachusetts cohorts appear very similar, it seems unlikely that the results in this section are driven by self-selection into the protected cohort of borrowers who are unlikely to cure.

One might expect that lenders could also have acted strategically when faced with the policy change in Massachusetts, though it is unlikely that such a scenario drives our results. In theory, lenders had an incentive to speed up foreclosures in the early spring of 2008 so that mortgages would be accelerated before May 1 and not receive the right-to-cure protection. There are two reasons why this possibility is unlikely to bias the results. First, most loans are originated using Fannie Mae and Freddie Mac uniform mortgage documents, which require that lenders wait at least 30 days between issuing the notice of default and accelerating the mortgage. So most lenders were contractually bound to the slower timeline and could not quickly accelerate mortgages. Second, although lenders would be legally allowed to send the notice of default sooner-after the borrower becomes 60-days delinquent rather than 90-days delinquent, for example - they would be unlikely to do so. Initiating foreclosure proceedings is costly for the lender and, since many borrowers cure their mortgage defaults before becoming seriously delinquent, this would amount to wasted effort on the lender's part. If lenders can determine which borrowers were least likely to cure and speed up the foreclosure process for those borrowers by sending the notice of default earlier, this would actually result in upwardly biased effects of the right-to-cure policy on borrower cures, since borrowers least likely to cure would be contaminating the control group. In summary, it seems unlikely that strategic behavior by borrowers or lenders is driving the absence of improvements in borrower cures following the implementation of the right-to-cure policy.

Perhaps the most important drawback to the analysis is the fact that we do not possess information on the exact date that the mortgages were accelerated and thus we cannot definitively categorize borrowers in Massachusetts as having received or not received the 90day right-to-cure period. As previously discussed, the standard timeline for issuing default notices, coupled with the required 30-day waiting period for accelerations that was built into standardized mortgage documents, gives us confidence that borrowers who became seriously delinquent after March 2008 received the right-to-cure protection. However, if lenders were slower to begin foreclosure proceedings, borrowers who became delinquent earlier in 2008 may also have received the protection. If this is the case, the borrowers who became seriously delinquent in March 2008 would be the most likely to be miscategorized. To check for this, we adjusted the original 3-month cohorts to categorize borrowers who became seriously delinquent in March 2008 as having received the right-to-cure protection. The results do 
not change substantively; cure probabilities for the 3-month horizon decreased slightly in Massachusetts relative to the comparison states, which is exactly what we found using the original cohort definitions.

\subsection{Discussion}

The results of this analysis, which are highly robust to alternative specifications and sample restrictions, suggest that the right-to-cure policy that Massachusetts implemented in 2008 had no impact on borrowers' ability to cure their mortgage defaults or obtain mortgage modifications. In fact, in some specifications, there is a small and marginally significant decline in cure probabilities at the earliest stage examined, three months after the borrower became seriously delinquent.

One potential explanation for our results that the law did not improve borrower outcomes is that the right-to-cure period was so short that it made little difference to borrowers in terms of postponing foreclosure while they sought new employment, found a buyer for the property, or worked with lenders to secure modifications. This idea seems to be the current assumption of Massachusetts policymakers, who in August 2010 extended the right-to-cure period to 150 days. Once adequate time has passed, it will be important to evaluate how borrower outcomes have been shaped by this extension. ${ }^{36}$

As for the small and marginally significant decline in early cure rates, some borrowers in Massachusetts may have simply taken advantage of the right-to-cure period to linger in default and put off curing, knowing that foreclosure was not imminent. Meanwhile, an additional 90 days may have made little difference for borrowers actively seeking modifications. Lenders, which face higher costs as a result of the longer foreclosure processes, could have even less incentive to modify loans after the right-to-cure period was introduced. Given that a very large proportion of borrowers who receive modification re-default on their mortgages, lenders may be hesitant to offer modifications to borrowers who receive longer foreclosure protections; if these borrowers re-default, it will take much longer to foreclose and will cost the lender even more.

\footnotetext{
${ }^{36}$ We have examined the 3 - and 6-month cure and modification rates of borrowers who became seriously delinquent in the months leading up to and following the August 2010 extension of the law. The results, shown in the appendix in Table A-13, seem to indicate that the extended right to cure has been no more successful at improving borrower outcomes than the original. However, these data only account for borrower outcomes through March 2011; the policy should be fully evaluated after more time has elapsed.
} 


\section{$5 \quad$ Policy Implications}

Do judicial intervention and the interposition of a right-to-cure period in the foreclosure process produce better outcomes? The answer to this question depends on how one defines outcomes. To analyze this, we first focus on the narrow goals of the laws-prevention of unjust or unnecessary foreclosures - and then consider the broader effect on the housing market and affected communities.

On their narrow goals, one has to conclude that both judicial foreclosure and right-tocure statutes are policy failures. We have shown that neither approach has any effect on the number of borrowers who cure their delinquencies. If the laws allowed borrowers to escape from unjust or unnecessary foreclosures, we would see more cures and more modifications, neither of which occurs. Of course, a finding that borrowers were more likely to cure would not necessarily imply that either law was effective policy, because both laws exact high costs in terms of delayed foreclosures; the lack of any appreciable benefit saves us the trouble of conducting such a cost-benefit analysis.

In a sense, the failure of judicial foreclosure to affect outcomes is not so surprising. Legal scholars have long argued that the power-of-sale procedure can replicate the protections of the judicial process at much lower cost. Nelson and Whitman (1985, 536), for example, write that

The underlying theory of power of sale foreclosure is simple. It is that by complying with the above type statutory requirements the [lender] accomplishes the same purposes achieved by judicial foreclosure without the substantial additional burdens that the latter type of foreclosure entails. Those purposes are to terminate all interests junior to the mortgage being foreclosed and to provide the sale purchaser with a title identical to that of the mortgagor as of the time the mortgage being foreclosed was executed.

It is important to understand that, despite the absence of direct supervision by the courts, the lender in a power-of-sale foreclosure has a strong incentive to follow the rules of law because any failure to do so clouds the title and reduces the value of the property. U.S. Bank v. Ibañez supra, illustrates this point: a title insurer raised questions about whether the lender had followed proper procedures, which led the lender to go to land court to get a judicial stamp of approval. Some even argue that, in some cases, the fact that the courts have rendered a final judgment when a judicial foreclosure occurs precludes the borrower from raising issues that he or she might be able to after a power-of-sale foreclosure.

Our results show that lenders already do exactly what the lawmakers want them to do. In Section 3.2, we argued that the hazard rates implied that lenders foreclose more intensively 
on the borrowers least likely to cure. In other words, borrowers who stand to benefit the most from additional time already get it. In Section 4, we showed that implementing a 90-day right-to-cure period had a big effect on the timing of foreclosure petitions but not on the timing of foreclosure sales, meaning, effectively, that borrowers already got a 90-day period to cure default.

But the laws obviously have broader effects and judging those effects is a far more nuanced task. At the crudest level, delaying the foreclosure process causes a wealth transfer from lender to borrower. The borrower lives rent-free while the lender loses interest income from the capital in the property and cannot get reimbursed for the depreciation. But there are other potential effects for the community as a whole.

Mian, Sufi, and Trebbi (2011) have argued that foreclosures depress house prices so therefore the judicial foreclosure process, which slows the pace of foreclosures, benefits the economy. Our results show that one must interpret any such claim with great caution. We have shown that the judicial procedure alters the timing but not the number of foreclosures. Thus, any test of the effect of different legal regimes on house prices is a joint test of the hypothesis that foreclosures drive down prices and that market participants are myopic and do not realize that there is a glut of foreclosed properties looming in judicial states. In fact, market commentators are equally as likely to attribute the weakness in the housing market to foreclosures as they are to "foreclosure overhang," the mass of what we call "persistently delinquent" borrowers for whom foreclosure is more or less inevitable.

Taking Mian, Sufi, and Trebbi's argument at face value, one might think that legal protections indirectly prevent foreclosures by slowing price declines and thus preventing delinquencies - that is, even if the laws do not prevent delinquencies from turning into foreclosures, they might prevent delinquencies from occurring in the first place. However, Mian, Sufi, and Trebbi $(2011,3)$ argue against this hypothesis, finding that "the rate at which homeowners default on their homes is almost identical in states that do and do not require judicial foreclosure. But the rate at which delinquencies progress into foreclosures is substantially lower in judicial requirement states."

The unambiguous effect of delaying foreclosure is that it lengthens the period for separation of ownership and control of residential property. As prominent housing economist Edward Glaeser writes:

Delinquent homeowners want to inhabit and to control their homes. Lenders want to get them out and to limit the damage done to the property. During the foreclosure process, home occupants have no reason to invest in their homes. Indeed, spite sometimes pushes them to abuse the property. [This] logic suggests that such periods ensure an abuse of the housing stock, which is one reason why 
homes often lose close to half of their value when they go through foreclosure. ${ }^{37}$

Indeed, of the 200 properties New York City cited in 2008 as the worst maintained, 77 were in the foreclosure process. ${ }^{38}$ Policies designed to protect borrowers from foreclosure may have the unintended consequence of aggravating the externalities - crime, vandalism, and inhumane living conditions for tenants among them-associated with failed home ownerships.

${ }^{37}$ Edward Glaeser, "Foreclosing the Crisis," The New Republic, February 4, 2009.

${ }^{38}$ Manny Fernandez and Jennifer Lee, "Struggling Landlords Leaving Repairs Undone," New York Times, July 14, 2009. 


\section{References}

Adelino, Manuel, Kristopher Gerardi, and Paul S. Willen. 2009. "Why Don't Lenders Renegotiate More Home Mortgages? Redefaults, Self-Cures, and Securitization." NBER Working Paper 15159. Cambridge, MA: National Bureau of Economic Research.

Collins, J. Michael, Ken Lam, and Christopher E. Herbert. 2011. "State Mortgage Foreclosure Policies and Lender Interventions: Impacts on Borrower Behavior in Default." Journal of Policy Analysis and Management 30(2): 216-232.

Cordell, Larry, and Vidya Shenoy. 2011. "The Cost of Delay." Manuscript. Philadelphia, PA: Federal Reserve Bank of Philadelphia.

Foote, Christopher, Kristopher Gerardi, Lorenz Goette, and Paul Willen. 2010. "Reducing Foreclosures: No Easy Answers." In NBER Macroeconomics Annual 2009, eds. Daron Acemoglu, Kenneth Rogoff, and Michael Woodford, vol. 24, chap. 2, 89-138. Chicago, IL: University of Chicago Press.

Mian, Atif, Amir Sufi, and Francesco Trebbi. 2011. "Foreclosures, House Prices, and the Real Economy." NBER Working Paper 16685. Cambridge, MA: National Bureau of Economic Research.

National Consumer Law Center. 2010. Foreclosures. The Consumer Credit and Sales Legal Practice Series, third edition. National Consumer Law Center.

Nelson, Grant S., and Dale A. Whitman. 1985. Real Estate Finance Law. Hornbook Series, Student Edition, second edition. St. Paul, MN: West Publishing.

Nelson, Grant S., and Dale A. Whitman. 2007. Real Estate Finance Law. Hornbook Series, Student Edition, fifth edition. St. Paul, MN: Thomson/West.

Osborne, George E. 1951. Handbook on the Law of Mortgages. Hornbook Series. St. Paul, MN: West Publishing.

Pennington-Cross, Anthony. 2010. "The Duration of Foreclosures in the Subprime Mortgage Market: A Competing Risks Model with Mixing." Journal of Real Estate Finance and Economics 40(2): 109-129.

Phillips, Richard A., and Eric M. Rosenblatt. 1997. "The Legal Environment and the Choice of Default Resolution Alternatives: An Empirical Analysis." Journal of Real Estate Research 13(2): 145-154. 
Phillips, Richard A., and James H. VanderHoff. 2004. "The Conditional Probability of Foreclosure: An Empirical Analysis of Conventional Mortgage Loan Defaults." Real Estate Economics 32(4): 571-587.

Rao, John, and Geoff Walsh. 2009. "Foreclosing a Dream: State Laws Deprive Homeowners of Basic Protections." Technical Report. Boston, MA: National Consumer Law Center. Available at http://www.nclc.org/images/pdf/foreclosure_mortgage/state_laws/ foreclosing-dream-report.pdf. 
Figure 1: Unconditional Cure and Foreclosure Hazards
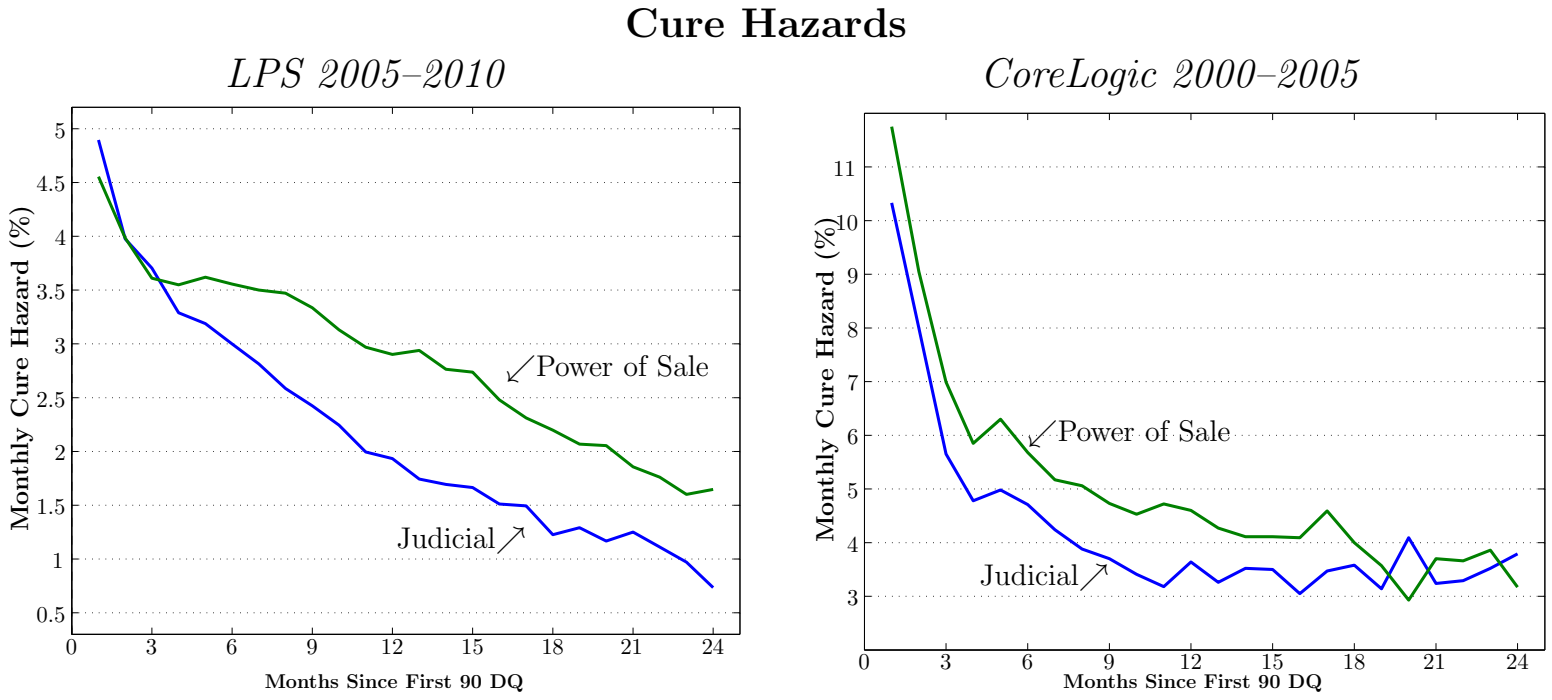

Foreclosure Hazards
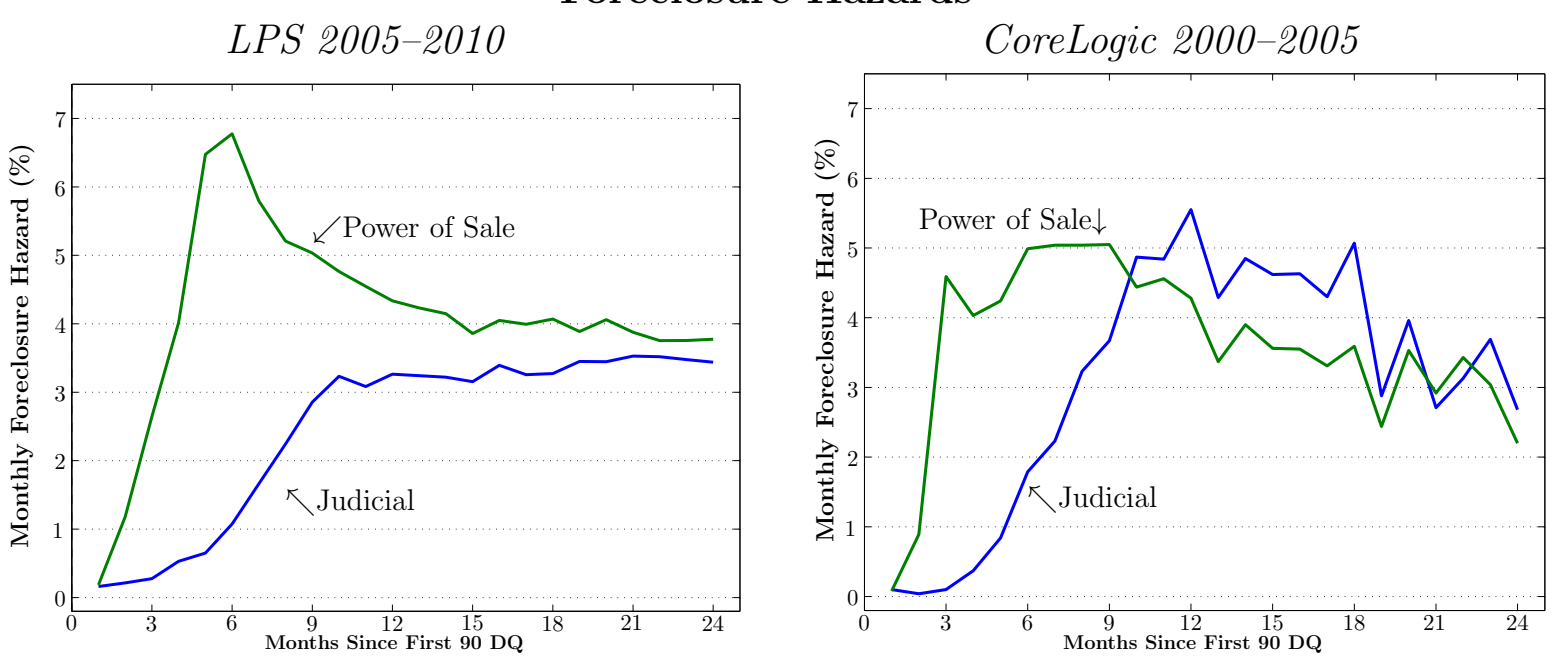

Source: Lender Processing Services (LPS), CoreLogic, and authors' calculations. 
Figure 2: Cumulative Incidence of Foreclosure and Cure Predicted With Hazard Model

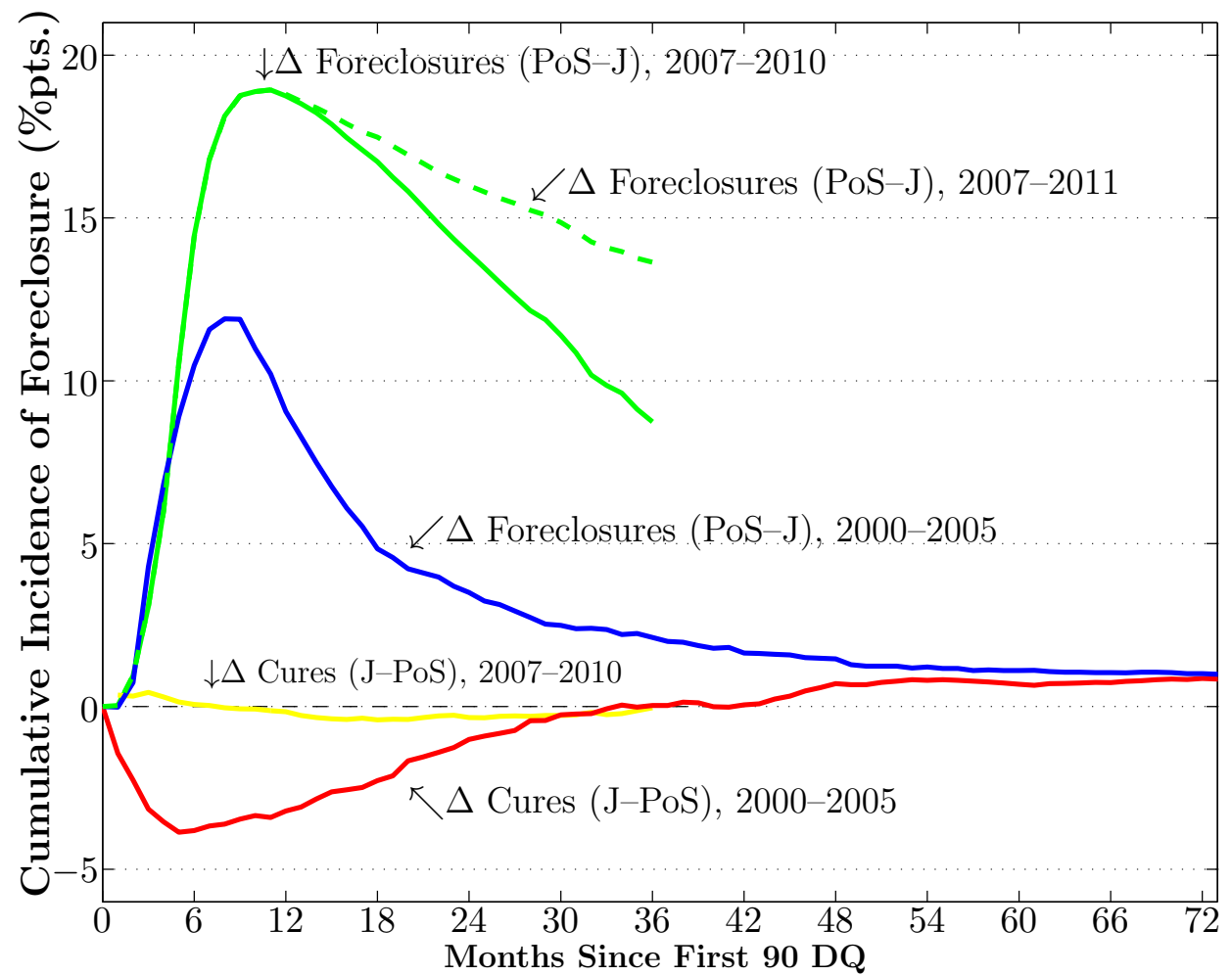

Source: Lender Processing Services (LPS) and authors' calculations.

Note: See Table 5 for estimates of hazard model for LPS sample. 
Figure 3: Foreclosure Petitions and Deeds

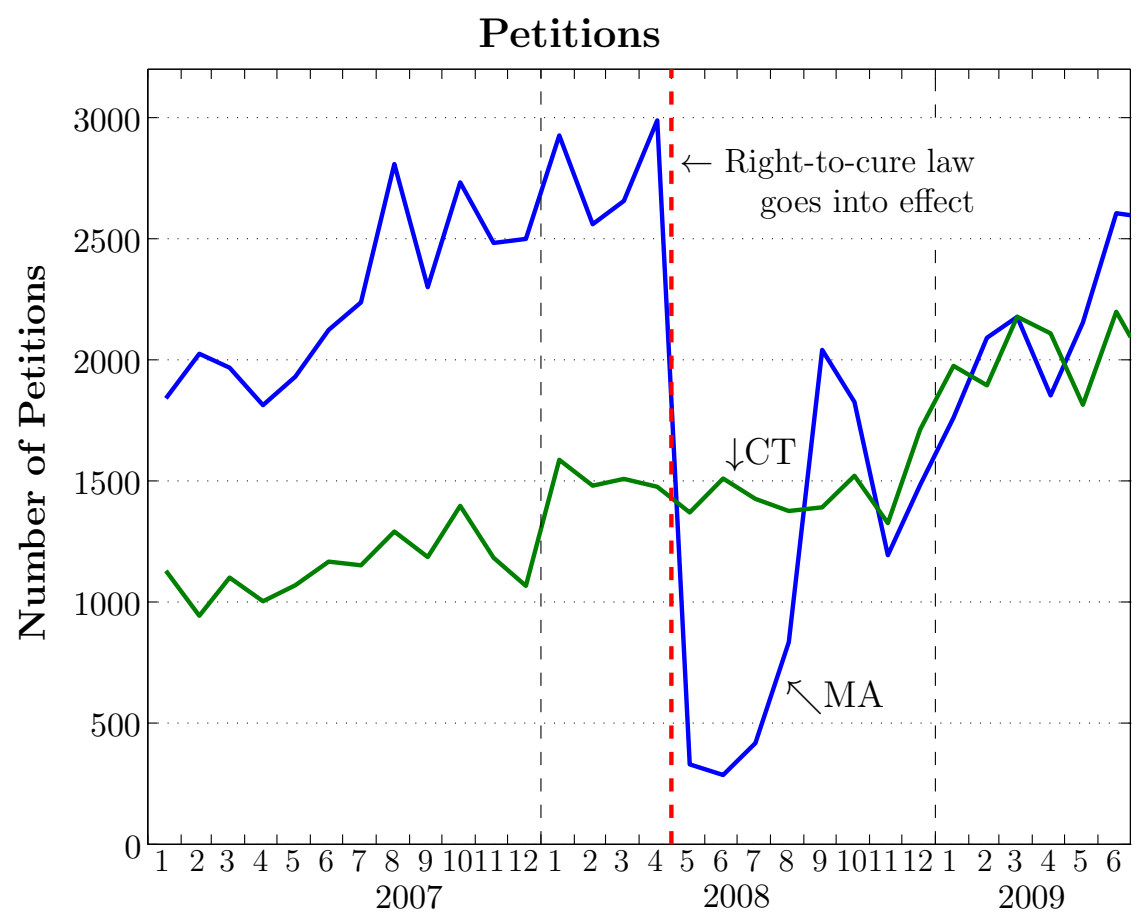

Deeds

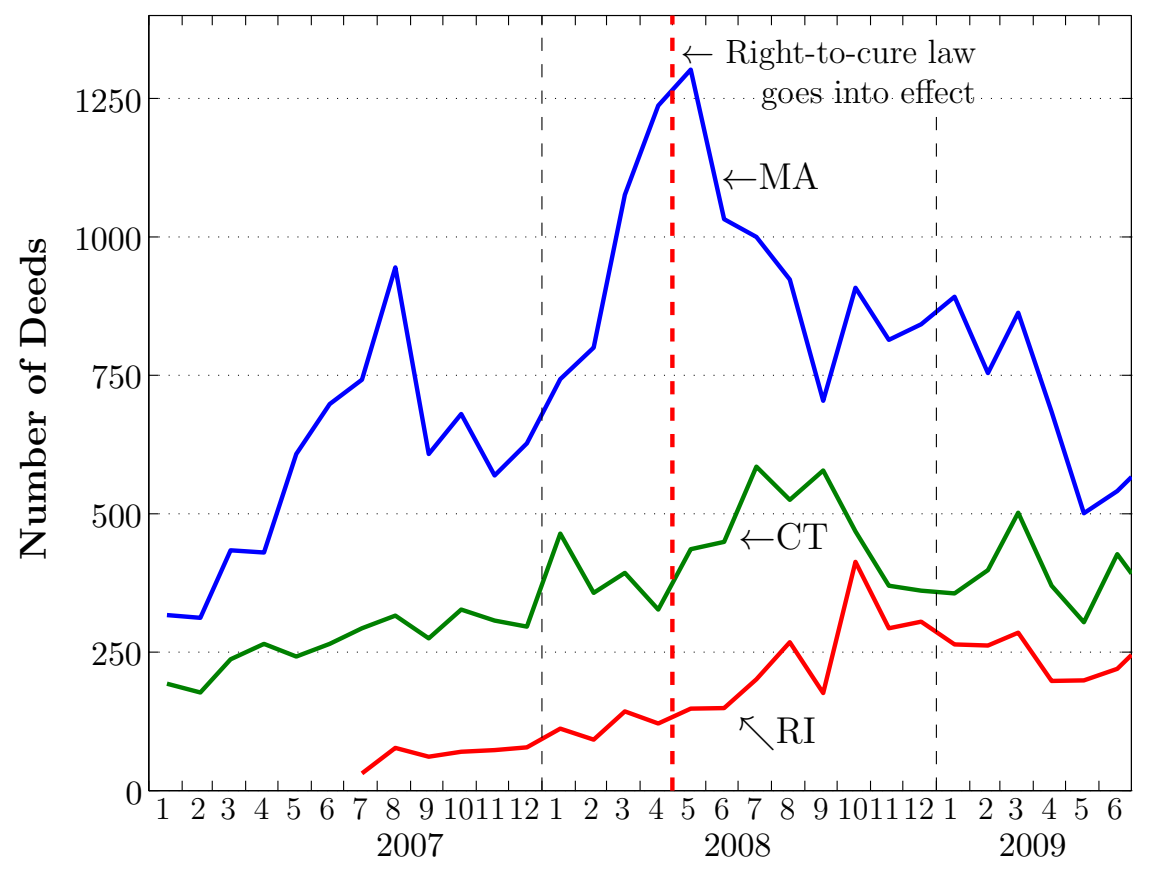

Source: The Warren Group and authors' calculations.

Note: Figure indicates deeds filed each month in Massachusetts, Connecticut, and Rhode Island between January 2007 and June 2009. Petition data are not available for Rhode Island. 
Figure 4: Fitted Probabilities of Cure and Modification
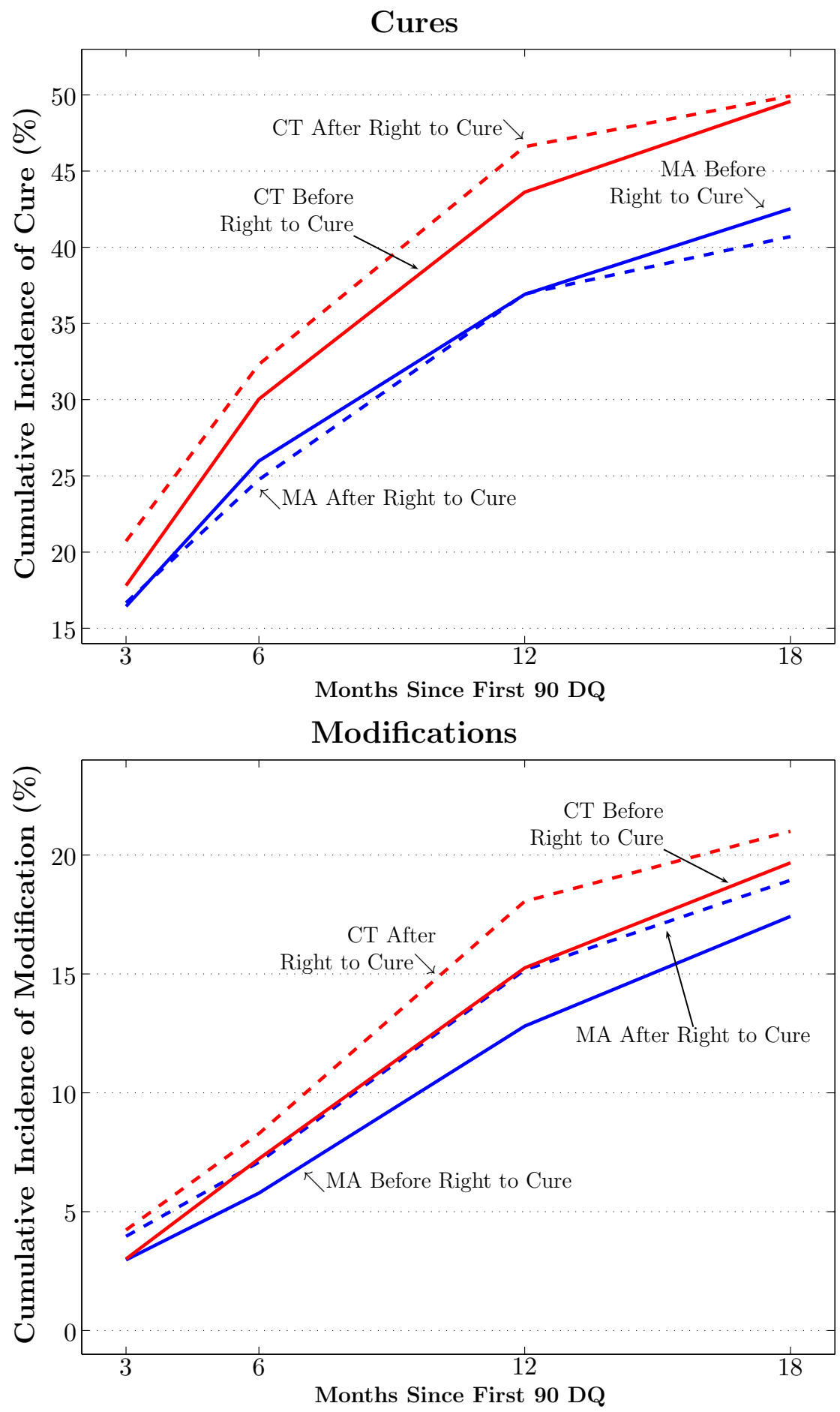

Source: Lender Processing Services (LPS) and authors' calculations.

Note: Cure and modification probabilities are based on the right-to-cure results for an average fixed-rate mortgage borrower in Massachusetts or Connecticut at $3,6,12$, and 18 months after becoming 90-days delinquent. 
Table 1: Summary Statistics

\begin{tabular}{|c|c|c|c|c|c|c|c|c|c|}
\hline & \multicolumn{3}{|c|}{ LPS 2005-2010 } & \multicolumn{3}{|c|}{ CoreLogic 2005-2010 } & \multicolumn{3}{|c|}{ CoreLogic 2000-2005 } \\
\hline & Power of Sale & Judicial & Total & Power of Sale & Judicial & Total & Power of Sale & Judicial & Total \\
\hline \multicolumn{10}{|l|}{ Average Characteristics at Origination } \\
\hline Origination Year & 2006 & 2006 & 2006 & 2006 & 2006 & 2006 & 2001 & 2001 & 2001 \\
\hline Loan-to-value Ratio (\%) & 81 & 82 & 82 & 81 & 82 & 81 & 79 & 79 & 79 \\
\hline FICO Score (range: $460-816$ ) & 654 & 648 & 652 & 643 & 631 & 638 & 582 & 581 & 582 \\
\hline \multicolumn{10}{|l|}{ Loan Purpose (\%) } \\
\hline Purchase & 51 & 54 & 52 & 49 & 49 & 49 & 33 & 33 & 33 \\
\hline Refinance & 49 & 46 & 48 & 51 & 51 & 51 & 67 & 67 & 67 \\
\hline \multicolumn{10}{|l|}{ Type of Mortgage Interest (\%) } \\
\hline Fixed Rate & 50 & 59 & 53 & 16 & 21 & 18 & 33 & 36 & 34 \\
\hline Adjustable Rate & 50 & 41 & 47 & 84 & 79 & 82 & 67 & 64 & 66 \\
\hline \multicolumn{10}{|l|}{ Occupancy Status (\%) } \\
\hline Primary Residence & 92 & 88 & 90 & 89 & 84 & 87 & 91 & 89 & 90 \\
\hline Second Home or Investment Property & 8 & 12 & 10 & 11 & 16 & 13 & 9 & 11 & 10 \\
\hline \multicolumn{10}{|l|}{ Property Type (\%) } \\
\hline Single Family & 87 & 78 & 84 & 87 & 77 & 83 & 94 & 88 & 91 \\
\hline Small Multi-Family (2-4 Units) & 2 & 5 & 3 & 5 & 11 & 7 & 3 & 9 & 6 \\
\hline Condominium & 11 & 17 & 13 & 8 & 12 & 10 & 3 & 3 & 3 \\
\hline \multicolumn{10}{|l|}{ Pre-delinquency Status } \\
\hline Months Elapsed & 19 & 18 & 19 & 19 & 18 & 19 & 16 & 17 & 16 \\
\hline Percent Change in House Price Index & -13 & -9 & -11 & -11 & -6 & -10 & 10 & 13 & 11 \\
\hline Change in Unemployment Rate & 1.5 & 1.5 & 1.5 & 1.2 & 1.1 & 1.1 & 0.8 & 0.7 & 0.8 \\
\hline \multicolumn{10}{|l|}{ Outcomes (\%) } \\
\hline Cured by 6 Months & 21 & 21 & 21 & 20 & 21 & 21 & 33 & 30 & 32 \\
\hline Modified by 6 Months & 10 & 9 & 10 & 10 & 10 & 10 & $\mathrm{n} / \mathrm{a}$ & $\mathrm{n} / \mathrm{a}$ & $\mathrm{n} / \mathrm{a}$ \\
\hline Observations & 101,740 & 58,751 & 160,491 & 85,167 & 47,069 & 132,236 & 10,482 & 7,142 & 17,624 \\
\hline
\end{tabular}

Source: Lender Processing Services (LPS), CoreLogic, and authors' calculations.

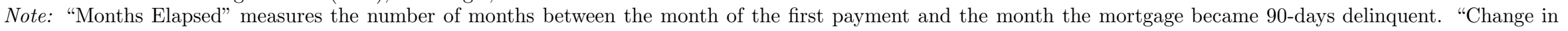

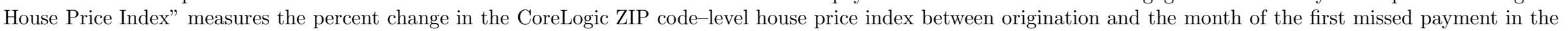
delinquency spell. "Change in Unemployment Rate" captures the change in the county-level unemployment rate between origination and delinquency. 
Table 2: Foreclosure Timelines

\begin{tabular}{|c|c|c|c|c|c|}
\hline \multicolumn{3}{|c|}{ Power of Sale } & \multicolumn{3}{|c|}{ Judicial } \\
\hline State & $\begin{array}{c}\text { Half-life } \\
\text { in Months }\end{array}$ & $\begin{array}{l}\% \text { Completed } \\
\text { at } 36 \text { Months }\end{array}$ & State & $\begin{array}{c}\text { Half-life } \\
\text { in Months }\end{array}$ & $\begin{array}{l}\% \text { Completed } \\
\text { at } 36 \text { Months }\end{array}$ \\
\hline $\mathrm{AK}$ & 9 & 61 & $\mathrm{CT}$ & $\geq 36$ & 41 \\
\hline $\mathrm{AL}$ & 34 & 50 & $\mathrm{DE}$ & $\geq 36$ & 32 \\
\hline $\mathrm{AR}$ & 20 & 54 & FL & $\geq 36$ & 40 \\
\hline $\mathrm{AZ}$ & 11 & 61 & IA & 32 & 51 \\
\hline $\mathrm{CA}$ & 18 & 56 & IL & $\geq 36$ & 47 \\
\hline $\mathrm{CO}$ & 12 & 59 & IN & $\geq 36$ & 50 \\
\hline $\mathrm{DC}$ & $\geq 36$ & 48 & KS & 16 & 56 \\
\hline GA & 18 & 55 & KY & $\geq 36$ & 50 \\
\hline HI & $\geq 36$ & 46 & LA & $\geq 36$ & 31 \\
\hline ID & 16 & 59 & $\mathrm{ME}$ & $\geq 36$ & 39 \\
\hline MA & $\geq 36$ & 47 & ND & $\geq 36$ & 48 \\
\hline MD & $\geq 36$ & 47 & NJ & $\geq 36$ & 30 \\
\hline MI & 9 & 61 & NY & $\geq 36$ & 26 \\
\hline $\mathrm{MN}$ & 10 & 62 & $\mathrm{OH}$ & 33 & 50 \\
\hline $\mathrm{MO}$ & 11 & 59 & PA & $\geq 36$ & 41 \\
\hline MS & $\geq 36$ & 49 & $\mathrm{SC}$ & $\geq 36$ & 49 \\
\hline $\mathrm{MT}$ & 35 & 50 & VT & $\geq 36$ & 38 \\
\hline $\mathrm{NC}$ & 27 & 51 & WI & 25 & 52 \\
\hline $\mathrm{NE}$ & 19 & 55 & & & \\
\hline $\mathrm{NH}$ & 17 & 55 & & & \\
\hline NM & $\geq 36$ & 46 & & & \\
\hline NV & 16 & 58 & & & \\
\hline OK & 25 & 52 & & & \\
\hline OR & 20 & 53 & & & \\
\hline RI & 21 & 53 & & & \\
\hline $\mathrm{SD}$ & 19 & 55 & & & \\
\hline TN & 26 & 52 & & & \\
\hline TX & 18 & 54 & & & \\
\hline UT & 28 & 51 & & & \\
\hline VA & 16 & 55 & & & \\
\hline WA & $\geq 36$ & 49 & & & \\
\hline WV & 23 & 53 & & & \\
\hline WY & 11 & 63 & & & \\
\hline
\end{tabular}


Table 3: Cumulative Incidence of Various Outcomes of Serious Delinquency

\begin{tabular}{|c|c|c|c|c|c|c|c|c|}
\hline & \multicolumn{4}{|c|}{3 Months } & \multicolumn{4}{|c|}{6 Months } \\
\hline & \multirow{2}{*}{$\begin{array}{c}(1) \\
\text { Power } \\
\text { of Sale }\end{array}$} & \multirow{2}{*}{$\frac{(2)}{\text { Judicial }}$} & \multicolumn{2}{|c|}{$(1)-(2)$} & \multirow{2}{*}{$\begin{array}{c}(3) \\
\text { Power } \\
\text { of Sale }\end{array}$} & \multirow{2}{*}{$\frac{(4)}{\text { Judicial }}$} & \multicolumn{2}{|c|}{$(3)-(4)$} \\
\hline & & & Raw & $\begin{array}{c}\text { With } \\
\text { Controls }\end{array}$ & & & Raw & $\begin{array}{c}\text { With } \\
\text { Controls }\end{array}$ \\
\hline Cured & 11.8 & 12.2 & -0.4 & 1.2 & 18.8 & 19.1 & -0.3 & 2.1 \\
\hline Modified & 5.7 & 4.9 & 0.8 & 0.6 & 10.3 & 8.8 & 1.5 & 1.4 \\
\hline Persistently Delinquent & 84.3 & 87.1 & -2.8 & -4.4 & 61.9 & 78.3 & -16.4 & -15.6 \\
\hline No foreclosure action & 40.6 & 39.0 & 1.7 & & 25.4 & 22.8 & 2.6 & \\
\hline Foreclosure proceedings started & 43.7 & 48.2 & -4.5 & & 36.5 & 55.5 & -19.0 & \\
\hline Foreclosed & 3.8 & 0.6 & 3.2 & 2.7 & 19.3 & 2.6 & 16.7 & 12.1 \\
\hline$R E O$ & 3.3 & 0.5 & 2.8 & & 16.8 & 1.9 & 14.9 & \\
\hline \multirow[t]{4}{*}{ Liquidated } & 0.5 & 0.2 & 0.4 & & 2.5 & 0.6 & 1.8 & \\
\hline & \multicolumn{4}{|c|}{12 Months } & \multicolumn{4}{|c|}{18 Months } \\
\hline & (1) & $(2)$ & \multicolumn{2}{|c|}{$(1)-(2)$} & $(3)$ & (4) & \multicolumn{2}{|c|}{$(3)-(4)$} \\
\hline & $\begin{array}{l}\text { Power } \\
\text { of Sale }\end{array}$ & Judicial & Raw & $\begin{array}{c}\text { With } \\
\text { controls }\end{array}$ & $\begin{array}{l}\text { Power } \\
\text { of Sale }\end{array}$ & Judicial & Raw & $\begin{array}{c}\text { With } \\
\text { controls }\end{array}$ \\
\hline Cured & 25.6 & 26.0 & -0.4 & 3.0 & 29.7 & 29.9 & -0.2 & 3.6 \\
\hline Modified & 15.7 & 13.7 & 2.0 & 2.2 & 19.4 & 17.5 & 1.9 & 2.4 \\
\hline Persistently Delinquent & 39.0 & 60.5 & -21.5 & -22.8 & 27.8 & 47.4 & -19.6 & -23.0 \\
\hline No foreclosure action & 13.6 & 11.1 & 2.5 & & 8.7 & 6.9 & 1.9 & \\
\hline Foreclosure proceedings started & 25.4 & 49.4 & -24.0 & & 19.0 & 40.5 & -21.5 & \\
\hline Foreclosed & 35.4 & 13.5 & 21.9 & 17.6 & 42.6 & 22.8 & 19.8 & 17.0 \\
\hline$R E O$ & 22.1 & 10.0 & 12.1 & & 17.6 & 13.6 & 4.1 & \\
\hline Liquidated & 13.3 & 3.5 & 9.8 & & 25.0 & 9.2 & 15.8 & \\
\hline
\end{tabular}

Source: Lender Processing Services (LPS) and authors' calculations.

Note: Sample includes borrowers who became delinquent from 2005 to 2009 observed through April 2011. Outcomes are defined in Section 3. Columns labeled "With controls" show the difference calculated using estimated parameters from the logit model described in Section 3 with parameter estimates in Table 4. 
Table 4: State Statute Results

\begin{tabular}{lccc}
\hline & Cure & Foreclosure & Modification \\
\hline Judicial & $0.861^{* * *}$ & $0.283^{* * *}$ & $0.850^{* * *}$ \\
& $(8.66)$ & $(63.13)$ & $(7.55)$ \\
Refinance & $1.162^{* * *}$ & $0.791^{* * *}$ & $1.241^{* * *}$ \\
Adjustable-rate Mortgage & $(8.64)$ & $(13.74)$ & $(10.30)$ \\
& $0.650^{* * *}$ & $1.974^{* * *}$ & $0.926^{* * *}$ \\
FICO at Origination & $(25.95)$ & $(39.96)$ & $(3.78)$ \\
& $0.995^{* * *}$ & $1.005^{* * *}$ & $0.993^{* * *}$ \\
Months Since First Payment & $(40.13)$ & $(37.19)$ & $(40.78)$ \\
& $1.013^{* * *}$ & $0.978^{* * *}$ & $1.023^{* * *}$ \\
LTV Ratio at Origination & $(14.67)$ & $(24.21)$ & $(21.52)$ \\
& $0.982^{* * *}$ & $1.017^{* * *}$ & $1.002^{*}$ \\
Owner Occupant & $(25.04)$ & $(19.60)$ & $(2.25)$ \\
& $1.511^{* * *}$ & $0.568^{* * *}$ & $1.865^{* * *}$ \\
Condominium & $(12.75)$ & $(21.05)$ & $(13.72)$ \\
& $0.848^{* * *}$ & $1.085^{* * *}$ & $0.812^{* * *}$ \\
Multi-family (2-4 units) & $(6.95)$ & $(3.73)$ & $(6.95)$ \\
& $0.774^{* * *}$ & $0.878^{* *}$ & 0.929 \\
Percent Change in House Price Index & $(5.14)$ & $(2.61)$ & $(1.16)$ \\
Change in Unemployment Rate & $\left(39.032^{* * *}\right.$ & $0.989^{* * *}$ & $1.002^{*}$ \\
& 1.008 & $(13.82)$ & $(2.24)$ \\
& $(1.33)$ & $\left(29.31^{* * *}\right.$ & $1.054^{* * *}$ \\
\hline Observations & 89,680 & 89,680 & $(7.38)$ \\
Chi-square & $7,547.54$ & $11,834.14$ & $3,137.96$ \\
Log Likelihood & $-47,282.63$ & $-47,148.67$ & $-35,098.58$ \\
\hline
\end{tabular}

Source: Lender Processing Services (LPS), CoreLogic, and authors' calculations.

Note: Cumulative cure, foreclosure, and modification results at 12 months. Displayed statistics are odds ratios with z-statistics in parentheses. ${ }^{* * *},{ }^{* *}$, and ${ }^{*}$ represent statistical significance at $0.1,1$, and 5 percent level, respectively. 
Table 5: Competing Risks Hazard Model of Cure and Foreclosure

\begin{tabular}{lcc}
\hline & Cure & Foreclosure \\
\hline Judicial & $0.294^{*}$ & $0.583^{\sim}$ \\
Refinance & $(2.30)$ & $(1.68)$ \\
& $1.115^{* * *}$ & $0.844^{* * *}$ \\
Adjustable-rate Mortgage & $(8.30)$ & $(15.67)$ \\
& $0.722^{* * *}$ & $1.315^{* * *}$ \\
FICO at Origination & $(25.20)$ & $(24.31)$ \\
& $0.996^{* * *}$ & $1.004^{* * *}$ \\
Months Since First Payment & $(37.02)$ & $(40.45)$ \\
& $1.009^{* * *}$ & $0.990^{* * *}$ \\
LTV Ratio at Origination & $(12.19)$ & $(15.99)$ \\
& $0.988^{* * *}$ & $1.006^{* * *}$ \\
Owner Occupant & $(22.94)$ & $(14.20)$ \\
Condominium & $1.473^{* * *}$ & $0.664^{* * *}$ \\
Multi-family (2-4 units) & $(14.36)$ & $(25.46)$ \\
Percent Change in House Price Index & $0.835^{* * *}$ & $1.089^{* * *}$ \\
Change in Unemployment Rate & $(9.66)$ & $(6.23)$ \\
& $0.788^{* * *}$ & $0.887^{* * *}$ \\
Observations (mortgages by month) & $(33.29)$ & $(3.94)$ \\
Log Likelihood & $0.972^{* * *}$ & $0.995^{* * *}$ \\
\hline Source: Lend & $(4.94)$ & $(13.26)$ \\
\hline & & $1,239,176$ \\
& & $44,498.66$ \\
& & 344.73 \\
\hline
\end{tabular}

Source: Lender Processing Services (LPS), CoreLogic, and authors' calculations. Note: Includes borrowers who became 90-days delinquent between January 2005 and February 2009. Displayed statistics are hazard ratios with z-statistics in parentheses. ${ }^{* * *},{ }^{* *},{ }^{*}$, and $\sim$ represent statistical significance at $0.1,1,5$, and 10 percent level, respectively. The model also includes a quadratic term for months elapsed since the mortgage became seriously delinquent, a set of dummy variables for the first 24 months after becoming seriously delinquent, interactions between the month dummies and Judicial, cohort dummies for the year the mortgage became seriously delinquent, and interactions between cohort dummies and Judicial. 
Table 6: Right-to-cure Results-Descriptive Statistics for Delinquency Cohorts

\begin{tabular}{|c|c|c|c|c|c|c|c|c|c|c|}
\hline & \multicolumn{10}{|c|}{ Month Loan Became 90-days Delinquent } \\
\hline & \multicolumn{5}{|c|}{ January-March 2008} & \multicolumn{5}{|c|}{ April-June 2008} \\
\hline & MA & $(\mathrm{RI}, \mathrm{CT}, \mathrm{NH})$ & RI & $\mathrm{CT}$ & $\mathrm{NH}$ & MA & $(\mathrm{RI}, \mathrm{CT}, \mathrm{NH})$ & RI & $\mathrm{CT}$ & $\mathrm{NH}$ \\
\hline \multicolumn{11}{|l|}{ Average Characteristics at Origination } \\
\hline Origination Year & 2006 & 2006 & 2006 & 2006 & 2006 & 2006 & 2006 & 2006 & 2006 & 2006 \\
\hline Loan-to-value Ratio (\%) & 79 & 80 & 80 & 80 & 79 & 78 & 80 & 79 & 80 & 79 \\
\hline FICO Score (range: 460-816) & 653 & 640 & 651 & 636 & 640 & 660 & 647 & 655 & 644 & 646 \\
\hline \multicolumn{11}{|l|}{ Loan Purpose (\%) } \\
\hline Purchase & 36 & 40 & 37 & 44 & 34 & 36 & 38 & 38 & 39 & 35 \\
\hline Refinance & 64 & 60 & 63 & 56 & 66 & 64 & 62 & 62 & 61 & 65 \\
\hline \multicolumn{11}{|l|}{ Type of Mortgage Interest (\%) } \\
\hline Fixed Rate & 56 & 62 & 60 & 61 & 66 & 60 & 63 & 63 & 60 & 71 \\
\hline Adjustable Rate & 44 & 38 & 40 & 39 & 34 & 40 & 37 & 37 & 40 & 29 \\
\hline \multicolumn{11}{|l|}{ Occupancy Status (\%) } \\
\hline Primary Residence & 93 & 93 & 92 & 93 & 92 & 92 & 92 & 92 & 92 & 90 \\
\hline Second Home or Investment Property & 7 & 7 & 8 & 7 & 8 & 8 & 8 & 8 & 8 & 10 \\
\hline \multicolumn{11}{|l|}{ Property Type (\%) } \\
\hline Single Family & 66 & 76 & 73 & 75 & 82 & 66 & 75 & 66 & 76 & 80 \\
\hline Small Multi-Family (2-4 Units) & 15 & 13 & 20 & 12 & 7 & 15 & 14 & 24 & 13 & 7 \\
\hline Condominium & 19 & 11 & 7 & 13 & 11 & 19 & 11 & 10 & 11 & 13 \\
\hline \multicolumn{11}{|l|}{ Pre-delinquency Status } \\
\hline Months Elapsed & 18 & 18 & 17 & 17 & 19 & 19 & 20 & 19 & 20 & 21 \\
\hline Previous 90-day Delinquency Spell & 2 & 2 & 1 & 2 & 3 & 2 & 2 & 2 & 2 & 2 \\
\hline Percent Change in House Price Index & -10 & -6 & -13 & -4 & -5 & -10 & -7 & -11 & -4 & -6 \\
\hline Change in Unemployment Rate & 0.38 & 1.02 & 2.03 & 0.84 & 0.41 & 0.14 & 0.86 & 2.09 & 0.63 & 0.07 \\
\hline \multicolumn{11}{|l|}{ Outcomes (\%) } \\
\hline Cured by 6 Months & 23 & 28 & 20 & 29 & 31 & 20 & 27 & 23 & 26 & 32 \\
\hline Modified by 6 Months & 9 & 11 & 9 & 12 & 13 & 10 & 12 & 11 & 12 & 13 \\
\hline Observations & 2,958 & 2,692 & 622 & 1,446 & 624 & 3,296 & 2,822 & 682 & 1,502 & 638 \\
\hline
\end{tabular}

Source: Lender Processing Services (LPS), CoreLogic, and authors' calculations.

Note: "Months Elapsed" measures the number of months between the month of the first payment and the month the mortgage became 90-days delinquent. "Change in House Price Index" measures the percent change in the CoreLogic ZIP code-level house price index between origination and the month of the first missed payment in the delinquency spell. "Change in Unemployment Rate" captures the change in the county-level unemployment rate between origination and delinquency. 
Table 7: Right-to-cure Results - Comparison of Cure and Modification Rates

\begin{tabular}{|c|c|c|c|c|c|c|}
\hline \multirow[b]{3}{*}{ Right-to-cure } & \multicolumn{3}{|c|}{ Cure } & \multicolumn{3}{|c|}{ Modification } \\
\hline & \multirow{2}{*}{$\begin{array}{c}\text { Full Sample } \\
1.122 \\
(1.58)\end{array}$} & \multicolumn{2}{|c|}{$\begin{array}{c}\text { Restricted } \\
\text { Sample }\end{array}$} & \multirow{2}{*}{$\begin{array}{c}\text { Full Sample } \\
1.428^{* *} \\
(2.81)\end{array}$} & \multicolumn{2}{|c|}{$\begin{array}{c}\text { Restricted } \\
\text { Sample }\end{array}$} \\
\hline & & $\begin{array}{l}1.223^{\sim} \\
(1.77)\end{array}$ & $\begin{array}{l}1.207 \\
(1.63)\end{array}$ & & $\begin{array}{l}1.466^{*} \\
(1.98)\end{array}$ & $\begin{array}{c}1.425^{\sim} \\
(1.8)\end{array}$ \\
\hline Massachusetts & $\begin{array}{l}0.847^{*} \\
(2.01)\end{array}$ & $\begin{array}{l}0.748^{*} \\
(2.35)\end{array}$ & $\begin{array}{l}0.908 \\
(0.71)\end{array}$ & $\begin{array}{c}0.97 \\
(0.21)\end{array}$ & $\begin{array}{l}0.777 \\
(1.18)\end{array}$ & $\begin{array}{l}0.985 \\
(0.06)\end{array}$ \\
\hline Massachusetts x Right-to-cure & $\begin{array}{l}0.826^{\sim} \\
(1.83)\end{array}$ & $\begin{array}{l}0.852 \\
(1.00)\end{array}$ & $\begin{array}{l}0.843 \\
(1.05)\end{array}$ & $\begin{array}{l}0.808 \\
(1.21)\end{array}$ & $\begin{array}{l}0.905 \\
(0.37)\end{array}$ & $\begin{array}{l}0.948 \\
(0.20)\end{array}$ \\
\hline Rhode Island & $\begin{array}{c}0.753^{* *} \\
(2.95)\end{array}$ & $\begin{array}{c}0.683^{* *} \\
(2.81)\end{array}$ & $\begin{array}{l}0.724^{\sim} \\
(1.85)\end{array}$ & $\begin{array}{l}0.651^{*} \\
(2.47)\end{array}$ & $\begin{array}{l}0.625^{*} \\
(2.02)\end{array}$ & $\begin{array}{l}0.768 \\
(0.89)\end{array}$ \\
\hline New Hampshire & $\begin{array}{l}1.246^{*} \\
(2.54)\end{array}$ & $\begin{array}{l}0.957 \\
(0.23)\end{array}$ & $\begin{array}{l}0.946 \\
(0.28)\end{array}$ & $\begin{array}{c}1.17 \\
(1.08)\end{array}$ & $\begin{array}{l}0.523 \\
(1.62)\end{array}$ & $\begin{array}{l}0.594 \\
(1.27)\end{array}$ \\
\hline Refinance & & & $\begin{array}{l}0.995 \\
(0.05)\end{array}$ & & & $\begin{array}{l}0.933 \\
(0.48)\end{array}$ \\
\hline Adjustable-rate Mortgage & & & $\begin{array}{c}0.579^{* * *} \\
(5.98)\end{array}$ & & & $\begin{array}{c}1.665^{* * *} \\
(3.52)\end{array}$ \\
\hline FICO at Origination & & & $\begin{array}{c}0.996^{* * *} \\
(5.33)\end{array}$ & & & $\begin{array}{c}0.993^{* * *} \\
(5.98)\end{array}$ \\
\hline Months Since First Payment & & & $\begin{array}{c}1.026^{* * *} \\
(5.3)\end{array}$ & & & $\begin{array}{c}1.039^{* * *} \\
(4.84)\end{array}$ \\
\hline LTV Ratio at Origination & & & $\begin{array}{c}0.988^{* * *} \\
(3.84)\end{array}$ & & & $\begin{array}{l}1.002 \\
(0.69)\end{array}$ \\
\hline Owner Occupant & & & $\begin{array}{l}1.615^{*} \\
(2.33)\end{array}$ & & & $\begin{array}{l}1.408 \\
(1.01)\end{array}$ \\
\hline Condominium & & & $\begin{array}{l}0.798^{\sim} \\
(1.89)\end{array}$ & & & $\begin{array}{l}1.053 \\
(0.28)\end{array}$ \\
\hline Multi-family (2-4 units) & & & $\begin{array}{c}0.691^{* *} \\
(2.79)\end{array}$ & & & $\begin{array}{l}0.773 \\
(1.19)\end{array}$ \\
\hline Percent Change in House Price Index & & & $\begin{array}{c}1.01 \\
(1.43)\end{array}$ & & & $\begin{array}{l}1.012 \\
(1.04)\end{array}$ \\
\hline Change in Unemployment Rate & & & $\begin{array}{c}1.08 \\
(1.19) \\
\end{array}$ & & & $\begin{array}{l}1.035 \\
(0.33) \\
\end{array}$ \\
\hline Observations & 11,522 & 5,327 & 5,327 & 11,423 & 5,282 & 5,282 \\
\hline Chi-square & 49.67 & 23.09 & 162.31 & 20.68 & 13.52 & 104.26 \\
\hline Log Likelihood & $-4,857.22$ & $-2,111.33$ & $-2,041.72$ & $-2,197.59$ & -972.69 & -927.32 \\
\hline
\end{tabular}

Source: Lender Processing Services (LPS), CoreLogic, and authors' calculations.

Note: Comparison of cure and modification rates reflects 6 months after entrance into serious delinquency for baseline and final models; excludes borrowers who were 90-days delinquent before January 2008. Sample size differs for modification and cure models because modification sample excludes some loans that experienced suspicious term changes and were thus left out of the estimation. Displayed statistics are odds ratios with z-statistics in parentheses. ${ }^{* * *},{ }^{* *},{ }^{*}$, and $\sim$ represent statistical significance at $0.1,1,5$, and 10 percent level, respectively. 